\title{
Chapter 3 \\ Relationships Between the Skull and the Face for Forensic Craniofacial Superimposition
}

\subsection{Introduction}

The evaluation of any superimposition is a significant issue that is dependent on the consistency of the anatomical link between the location of the soft tissue surfaces relative to the underlying bone (Taylor and Brown 1998).

In order to evaluate this consistency, a full comprehension of the anatomy of the skull and the relationship between the skull and the face are required. In biological organisms, structure and function are closely related. The human head, in terms of function, is related to four of the five senses: stereoscopic vision (eyes), audition (ears), gustation (tongue/mouth), and olfaction (nose), along with the protection of the brain. These functions are responsible for the structure of the head, and therefore the form of the face and the skull will be directly related to the position of the brain, eyes, ears, mouth, and nose.

From an anthropological perspective, the reliability of CFS and an identification based on this technique are evaluated mainly on the basis of the consistency between the anatomical structures of the face and skull.

The forensic expert usually relies on the analysis of anatomical criteria such as the soft tissue thickness, outlines, and positional relationships between the skull and the face. In the scientific literature, there are several studies conducted to assess the quality/degree of matching in CFS as well as to examine the criteria used to conduct this assessment. Before reviewing the different studies, Martin and Saller's studies (1957) must be considered. They created a treatise in which the fundamental pillars of this discipline were established. They defined an important set of craniometric and somatometric points (Tables 3.1, 3.2, and 3.3) that are crucial for all anthropological studies (Figs. 3.1, 3.2, 3.3, 3.4, 3.5, and 3.6).

A correct evaluation of anatomical consistency between facial and cranial structures is of paramount importance for reliable CFS. Generating accurate data on soft tissue thickness and the positioning of facial structures are important steps to improve current practices in craniofacial identification. At the moment, there is a 
Table 3.1 Craniometric points from Martin (1914) study (neurocranium)

Craniometric points: neurocranium

\begin{tabular}{l|l|l|l|l|l}
\hline ast & asterion & $\mathrm{ft}$ & frontotemporale & $\mathrm{ms}$ & mastoideale \\
\hline $\mathrm{au}$ & auriculare & $\mathrm{g}$ & glabella & o & opisthion \\
\hline $\mathrm{b}$ & bregma & $\mathrm{i}$ & inion & op & opisthocranion \\
\hline $\mathrm{ba}$ & basion & 1 & lambda & po & porion \\
\hline eu & euryon & $\mathrm{m}$ & metopion & so & supraorbitale \\
\hline
\end{tabular}

Taken from Martin and Saller (1957)

Table 3.2 Craniometric points from Martin (1914) study (splanchnocranium)

\begin{tabular}{l|l|l|l|l|l}
\hline \multicolumn{6}{l}{ Craniometric points: splanchnocranium } \\
\hline $\mathrm{d}$ & dacryon & $\mathrm{n}$ & nasion & rhi & rhinion \\
\hline gn & gnathion & $\mathrm{ns}$ & nasospinale & zo & zygoorbitale \\
\hline go & gonion & or & orbitale & zm & zygomaxillare \\
\hline $\mathrm{ml}$ & mentale & $\mathrm{pg}$ & pogonion & zy & zygion \\
\hline $\mathrm{mf}$ & maxillo-frontale & $\mathrm{pr}$ & prosthion & & \\
\hline
\end{tabular}

Taken from Knußmann (1988)

Table 3.3 Somatometric points from Martin (1914) study

\begin{tabular}{|c|c|c|c|c|c|c|c|}
\hline al & alare & g & glabellare & $\mathrm{ma}$ & mastoidale & $\mathrm{pr}$ & prosthion \\
\hline cdl & $\begin{array}{l}\text { condylion } \\
\text { laterale }\end{array}$ & go & gonion & $\mathrm{n}$ & nasion & prn & pronasale \\
\hline ch & cheilion & I & inion & or & orbitale & ps & $\begin{array}{l}\text { palpebrale } \\
\text { superius }\end{array}$ \\
\hline en & endocanthion & labm & labiomentale & os & $\begin{array}{l}\text { orbitale } \\
\text { superius }\end{array}$ & $\mathrm{sa}$ & superaulare \\
\hline eu & euryon & li & labrale inferius & $\mathrm{pg}$ & pogonion & sba & subaurale \\
\hline ex & exocanthion & 1s & $\begin{array}{l}\text { labrale } \\
\text { superius }\end{array}$ & pi & $\begin{array}{l}\text { palpebral } \\
\text { inferius }\end{array}$ & sci & superciliare \\
\hline $\mathrm{ft}$ & frontotemporale & $\mathrm{m}$ & metopion & po & porion & $\mathrm{se}$ & sellion \\
\hline gn & gnathion & op & opisthocranion & $\mathrm{pu}$ & pupilare & sn & subnasale \\
\hline sto & stomion & $\mathrm{t}$ & tragion & $\operatorname{tr}$ & trichion & $\mathrm{v}$ & vertex \\
\hline zy & zygion & & & & & & \\
\hline
\end{tabular}

Taken from Knußmann (1988)

clear lack of consensus in methodological approaches for CFS. The development of standard protocols is necessary to enhance the credibility of the technique, making it more readily admissible in judicial processes.

\subsection{Anthropometrical Relationships}

Understanding the relationship between the skull and the facial soft tissue has major relevance for forensic identification. Facial soft tissue thickness, measured as the distance from the skin surface to the most superficial surface of the underlying 


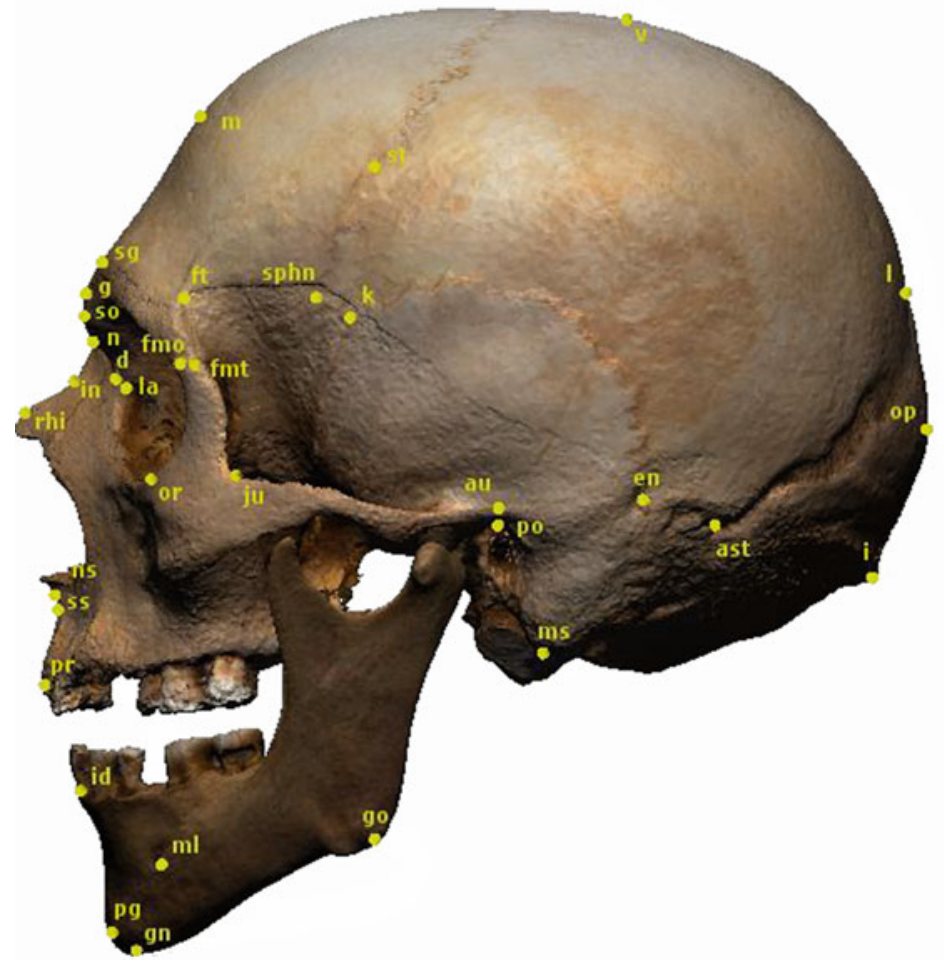

Fig. 3.1 Craniometric points in lateral view. Taken from Knußmann (1988)
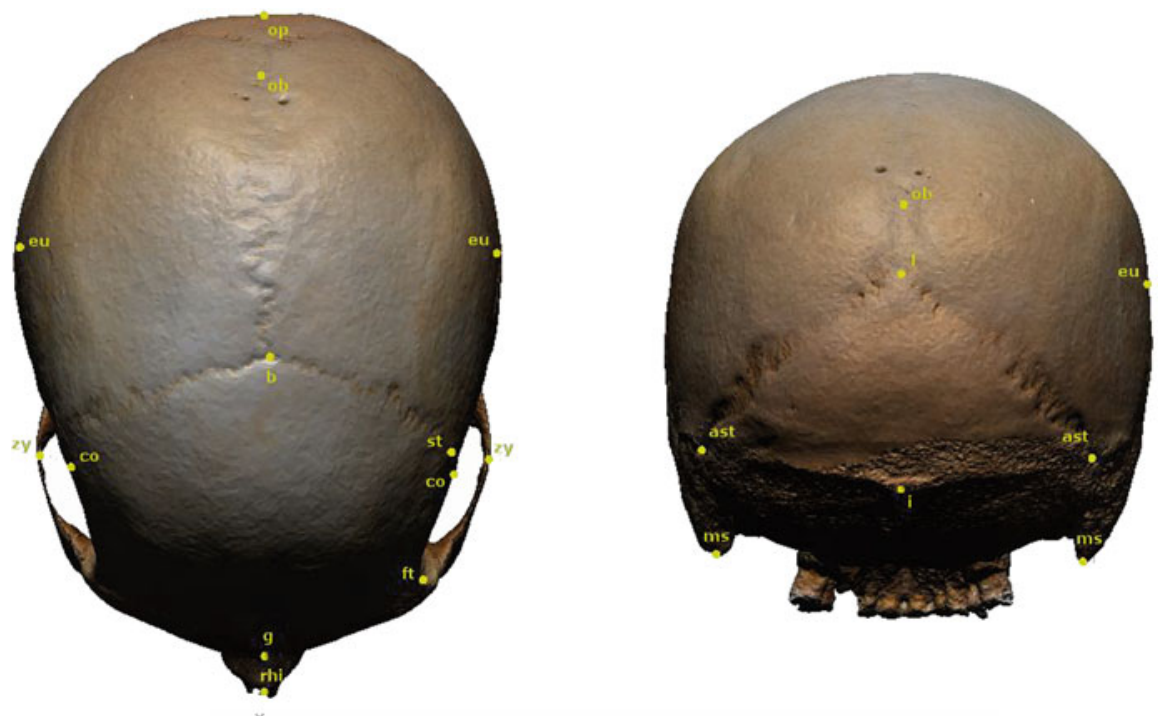

Fig. 3.2 Craniometric point in vertical view (left) and in occipital view (right). Taken from Knußmann (1988) 


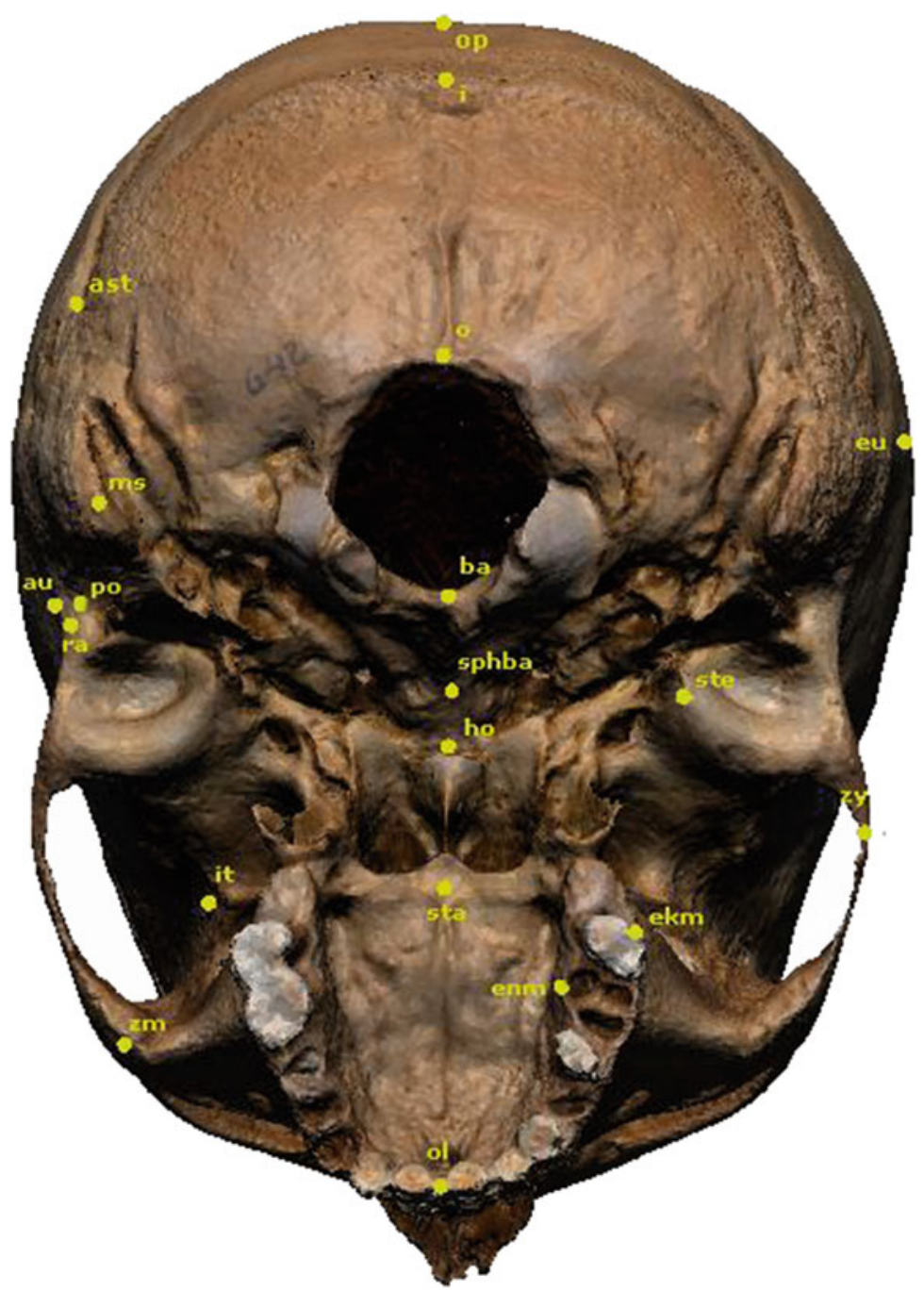

Fig. 3.3 Craniometric points in basilar view. Taken from Knußmann (1988)

skeletal tissue at specific landmarks, provides an important criterion for the evaluation of anatomical consistency. This kind of measurement provides general information on the match between the face and the skull, using facial soft tissue thickness as a means to control the outer contour of the face during the superimposition (Codinha and Fialho 2010; Stephan and Simpson 2008).

Due to the scientific value of facial soft tissue thickness in craniofacial identification, numerous studies have been conducted since 1883, with a great variation in measuring techniques, sample size, population ancestry, anatomical landmarks, and variables analyzed (e.g., sex, age, and body composition) (Codinha and Fialho 2010; Stephan and Simpson 2008). 


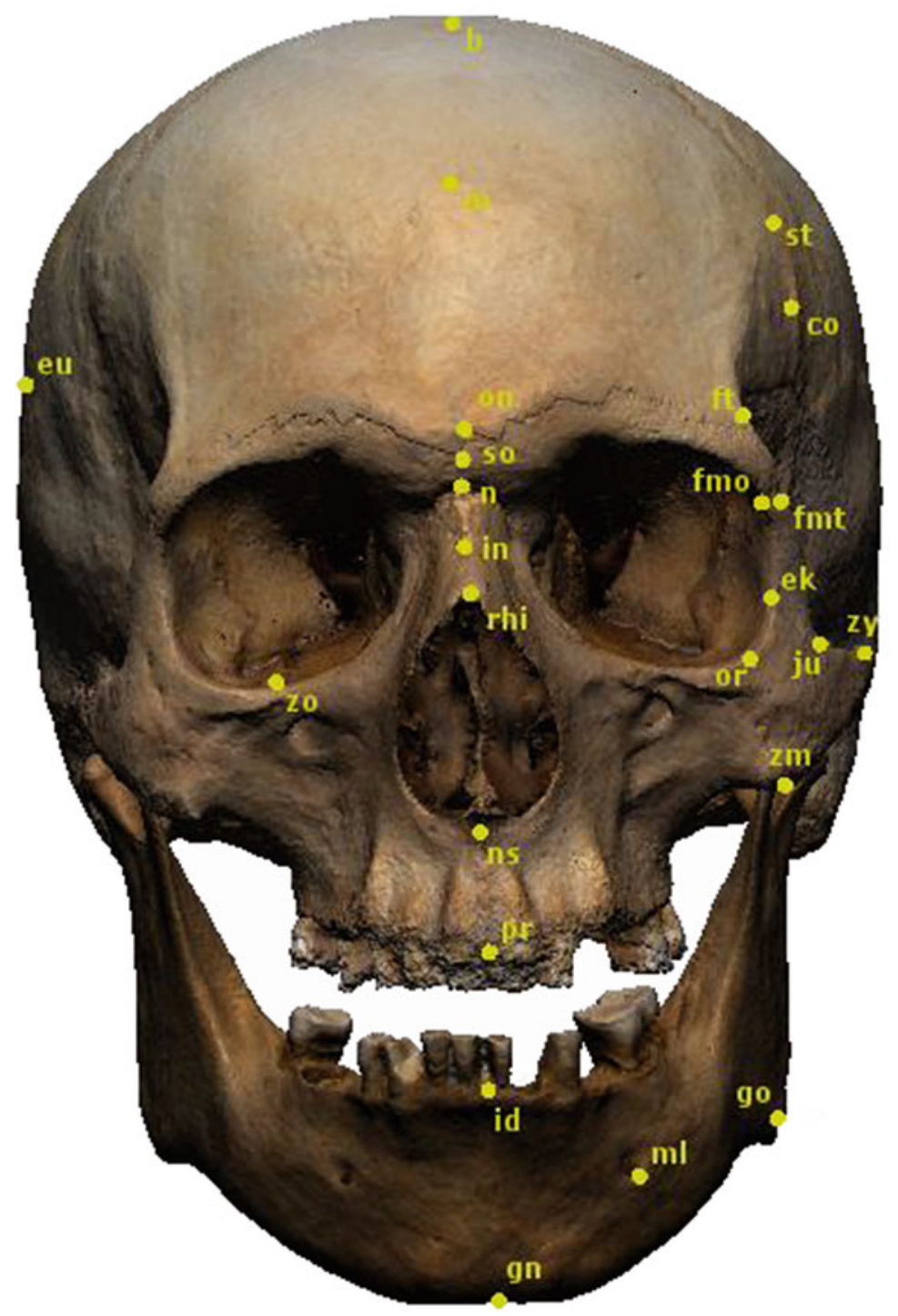

Fig. 3.4 Craniometric points in frontal view. Taken from Knußmann (1988)

Some of the main modalities for soft tissue thickness acquisition mentioned in the literature include:

- Needle puncture (Codinha and Fialho 2010; Simpson and Henneberg 2002; Domaracki and Stephan 2006; Rhine and Campbell 1980; Suzuki 1948; Birkner 1905; Stadtmuller 1925; Rhine et al. 1982; Galdames et al. 2008; His 1895; von Eggeling 1909) 


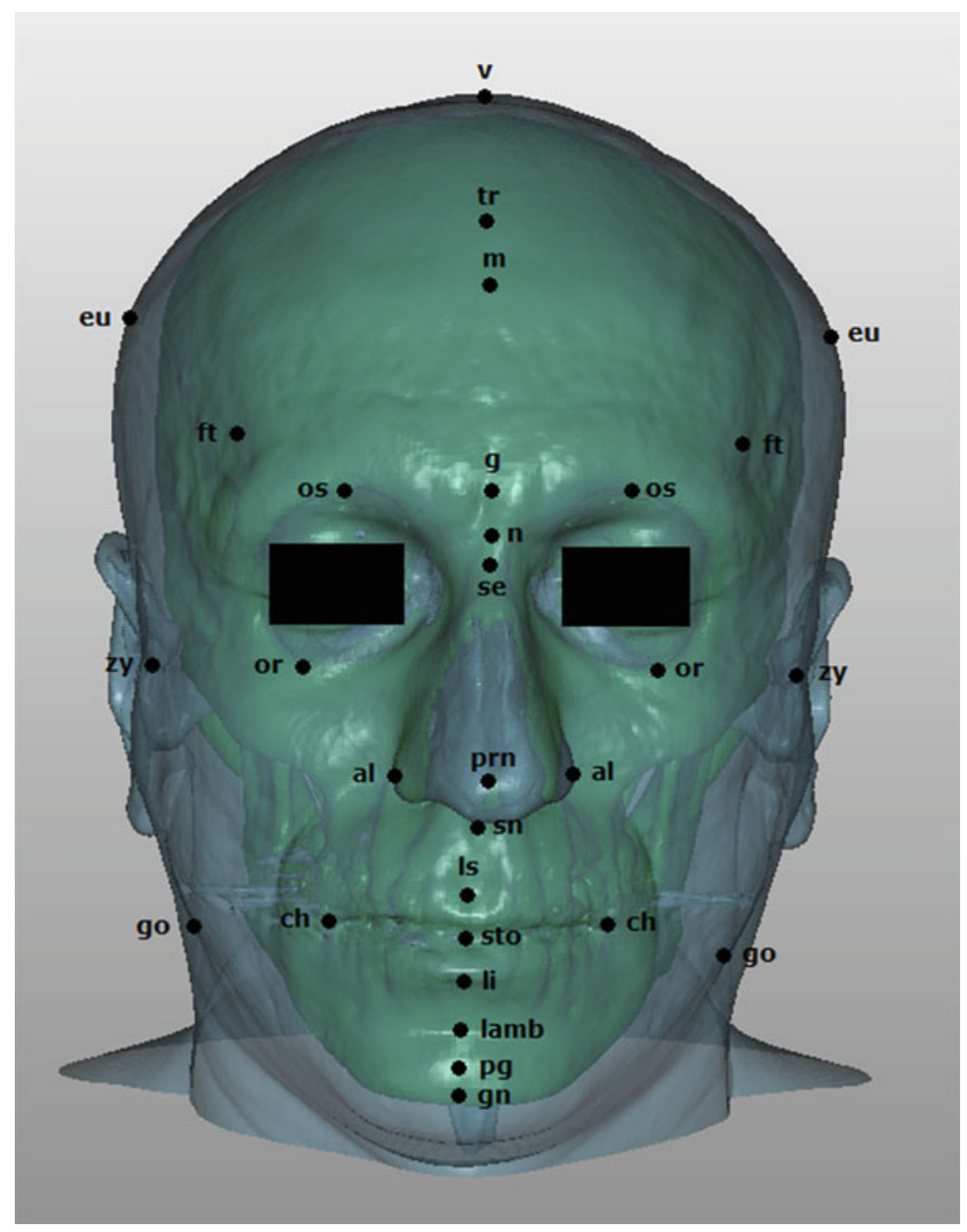

Fig. 3.5 Somatometric points in frontal view

- Cephaloradiography (George 1987; Leopold 1968; Weinig 1958; Bankowski 1958)

- Ultrasound imaging (Aulsebrook et al. 1996; Wilkinson 2002)

- Computer-assisted tomography (CT) (Phillips and Smuts 1996)

- Cone-beam CT (Bankowski 1958)

- Magnetic resonance imaging (Sahni 2002)

A summary of the most important soft tissue thickness studies and their main characteristics are listed in Table 3.4. None of these methodologies offer a perfect solution, as each technique has advantages and disadvantages. For example, needle puncture methods are inexpensive, but cadaveric material is not wholly 


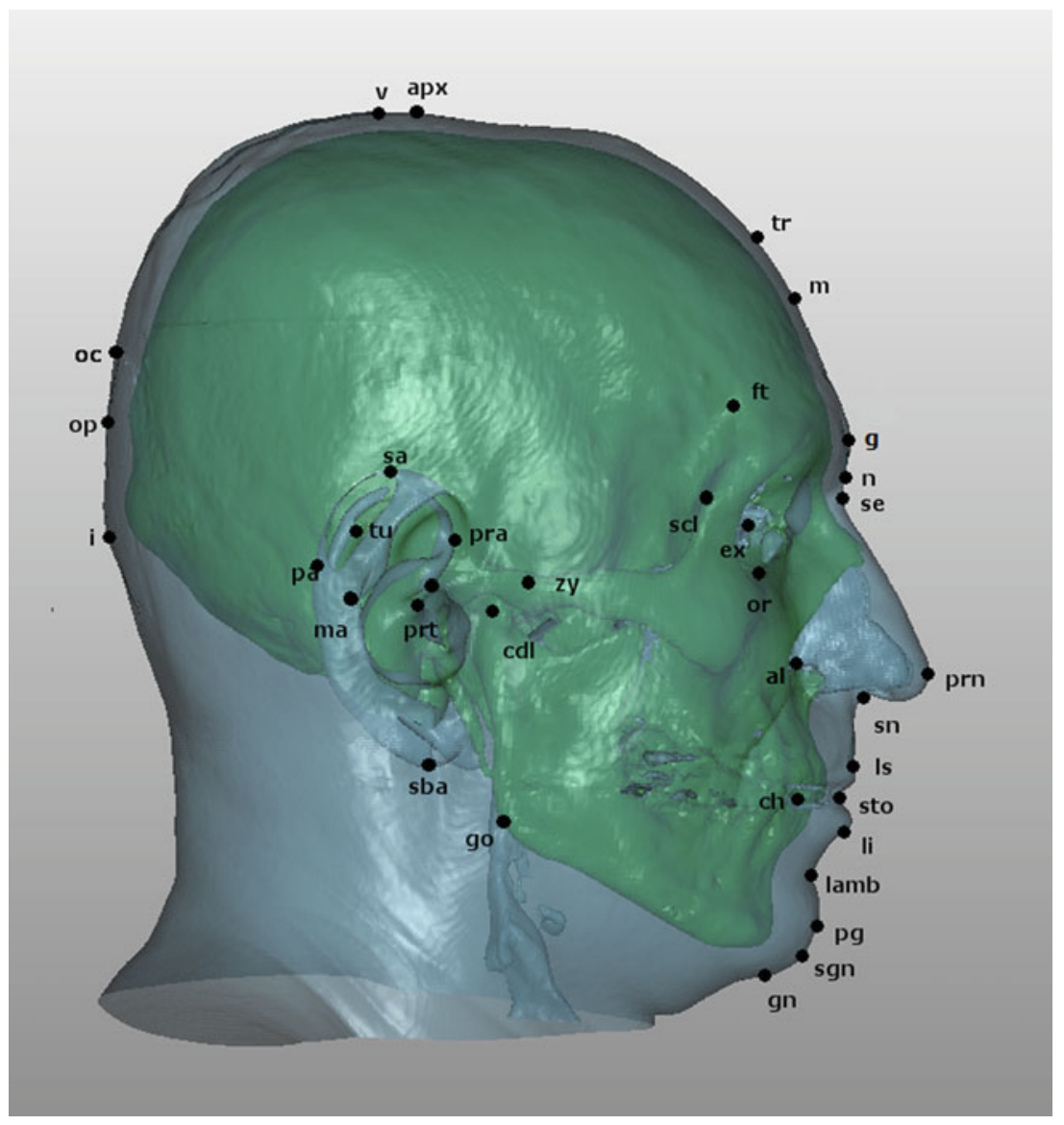

Fig. 3.6 Somatometric points in lateral view

representative of living subjects; CT scans are accurate and reproducible but may present gravity effects on the supine face, artifacts, and radiation damage; craniographs are inexpensive and the subject is upright, but the images can suffer from magnification and planar issues; ultrasound can be used on upright living subjects but involves contact and pressure issues. A more extensive list of advantages and disadvantages of the different methodologies used in soft tissue data collection was analyzed in Stephan and Simpson (2008) and in Preedy (2012). The latter is summarized in Tables 3.5 and 3.6.

The soft tissue thickness depth measurements are applied in facial depiction, but if they are used in CFS, changes due to facial expression must also be considered when determining identity. These measurements are usually, but not always, perpendicular to the bony structures, and are most useful if the image shows the soft tissue directly to the point of measurement (Clement and Ranson 1998). 
Table 3.4 Landmarks used by authors, sample, and methodology

\begin{tabular}{|c|c|c|c|c|c|c|c|}
\hline Reference & Date & $\begin{array}{l}\text { Number } \\
\text { of points }\end{array}$ & Male & Female & Total & Population $^{\mathrm{a}}$ & Methods \\
\hline Welcker & 1883 & 7 & 13 & & 13 & $\begin{array}{l}\text { White } \\
\text { (Cadavers) }\end{array}$ & $\begin{array}{l}\text { Tissue punc- } \\
\text { ture by using } \\
\text { needle }\end{array}$ \\
\hline His & 1895 & 15 & 24 & 4 & 28 & $\begin{array}{l}\text { White } \\
\text { (Cadavers) }\end{array}$ & $\begin{array}{l}\text { Tissue punc- } \\
\text { ture by using } \\
\text { needle }\end{array}$ \\
\hline $\begin{array}{l}\text { Kollmann } \\
\text { and Buchly }\end{array}$ & 1898 & 18 & 21 & 4 & 25 & $\begin{array}{l}\text { White European } \\
\text { (Cadavers) }\end{array}$ & $\begin{array}{l}\text { Tissue punc- } \\
\text { ture by using } \\
\text { needle }\end{array}$ \\
\hline Fischer & 1905 & 18 & 2 & & 2 & $\begin{array}{l}\text { Mongoloid } \\
\text { (Papuans) }\end{array}$ & $\begin{array}{l}\text { Tissue punc- } \\
\text { ture by using } \\
\text { needle }\end{array}$ \\
\hline Birkner & 1905 & 18 & 9 & & 6 & $\begin{array}{l}\text { Mongoloid } \\
\text { (Chinese) }\end{array}$ & $\begin{array}{l}\text { Tissue punc- } \\
\text { ture by using } \\
\text { needle }\end{array}$ \\
\hline Czekanowski & 1907 & 6 & 64 & 51 & 112 & $\begin{array}{l}\text { White Cauca- } \\
\text { sian (Cadavers) }\end{array}$ & $\begin{array}{l}\text { Tissue punc- } \\
\text { ture by using } \\
\text { needle }\end{array}$ \\
\hline $\begin{array}{l}\text { Von } \\
\text { Eggeling }\end{array}$ & 1909 & 18 & 3 & & 3 & $\begin{array}{l}\text { Black } \\
\text { (Hererons) }\end{array}$ & $\begin{array}{l}\text { Tissue punc- } \\
\text { ture by using } \\
\text { needle }\end{array}$ \\
\hline Stadtmuller & $\begin{array}{l}1923- \\
1925\end{array}$ & 20 & 15 & 3 & 18 & $\begin{array}{l}\text { Mongoloid, } \\
\text { White }\end{array}$ & $\begin{array}{l}\text { Tissue punc- } \\
\text { ture by using } \\
\text { needle }\end{array}$ \\
\hline Suzuki & 1948 & 18 & 7 & 48 & 55 & $\begin{array}{l}\text { Mongoloid } \\
\text { (Japanese) }\end{array}$ & $\begin{array}{l}\text { Tissue punc- } \\
\text { ture by using } \\
\text { needle }\end{array}$ \\
\hline Weinig & 1958 & 10 & 99 & 21 & 120 & $\begin{array}{l}\text { White Ameri- } \\
\text { cans (Living) }\end{array}$ & Craniographs \\
\hline Bankowski & 1958 & 13 & 15 & 9 & 24 & $\begin{array}{l}\text { White } \\
\text { Europeans } \\
\text { (Living) }\end{array}$ & Craniographs \\
\hline Berger & 1965 & 14 & 26 & 102 & 128 & $\begin{array}{l}\text { White Cauca- } \\
\text { sian (Cadavers) }\end{array}$ & $\begin{array}{l}\text { Tissue punc- } \\
\text { ture by using } \\
\text { needle }\end{array}$ \\
\hline Leopold & 1968 & 13 & 102 & 52 & 154 & $\begin{array}{l}\text { White } \\
\text { Europeans } \\
\text { (Cadavers) }\end{array}$ & Craniographs \\
\hline Sutton & 1969 & & & & 104 & $\begin{array}{l}\text { White Cauca- } \\
\text { sian (Cadavers) }\end{array}$ & $\begin{array}{l}\text { Tissue punc- } \\
\text { ture by using } \\
\text { needle }\end{array}$ \\
\hline $\begin{array}{l}\text { Rhine and } \\
\text { Campbell }\end{array}$ & 1980 & 21 & 44 & 15 & 59 & $\begin{array}{l}\text { American Black } \\
\text { (Unembalmed } \\
\text { cadavers) }\end{array}$ & $\begin{array}{l}\text { Needle and } \\
\text { rubber-stopper } \\
\text { technique }\end{array}$ \\
\hline
\end{tabular}


Table 3.4 (continued)

\begin{tabular}{|c|c|c|c|c|c|c|c|}
\hline Reference & Date & $\begin{array}{l}\text { Number } \\
\text { of points }\end{array}$ & Male & Female & Total & Population $^{\mathrm{a}}$ & Methods \\
\hline Farkas & 1981 & 132 & & & & $\begin{array}{l}\text { White (Cauca- } \\
\text { sian North } \\
\text { American } \\
\text { population) }\end{array}$ & \\
\hline Rhine et al. & 1982 & 21 & 37 & 19 & 56 & $\begin{array}{l}\text { American White } \\
\text { Caucasian } \\
\text { (Unembalmed } \\
\text { cadavers) }\end{array}$ & $\begin{array}{l}\text { Tissue punc- } \\
\text { ture by using } \\
\text { needle }\end{array}$ \\
\hline Rhine & 1983 & 21 & 9 & 2 & 11 & $\begin{array}{l}\text { South-western } \\
\text { Indians } \\
\text { (Cadavers) }\end{array}$ & $\begin{array}{l}\text { Tissue punc- } \\
\text { ture by using } \\
\text { needle }\end{array}$ \\
\hline Helmer & 1984 & 34 & 61 & 62 & 123 & $\begin{array}{l}\text { White European } \\
\text { (Living) }\end{array}$ & Ultrasound \\
\hline Hodson et al. & 1985 & 20 & & & 50 & $\begin{array}{l}\text { American } \\
\text { Caucasians }\end{array}$ & Ultrasound \\
\hline Dumont & 1986 & 9 & 93 & 101 & 194 & Caucasian & X-Ray \\
\hline George & 1987 & 10 & 17 & 37 & 54 & $\begin{array}{l}\text { Whites Ameri- } \\
\text { can (Living) }\end{array}$ & $\begin{array}{l}\text { Lateral } \\
\text { craniographs }\end{array}$ \\
\hline $\begin{array}{l}\text { Nanda and } \\
\text { Meng }\end{array}$ & 1990 & 4 & 17 & 23 & 40 & Caucasian & X-Ray \\
\hline $\begin{array}{l}\text { Aulsebrook } \\
\text { et al. }\end{array}$ & 1996 & - & 55 & & 55 & $\begin{array}{l}\text { Zulu (Living) } \\
\text { Negroids }\end{array}$ & $\begin{array}{l}\text { Lateral, } \\
\text { oblique cepha- } \\
\text { lometry } \\
\text { ultrasound }\end{array}$ \\
\hline $\begin{array}{l}\text { Phillips and } \\
\text { Smuts }\end{array}$ & 1996 & 21 & 16 & 16 & 32 & $\begin{array}{l}\text { Mixed raced } \\
\text { South Africans } \\
\text { (Living) }\end{array}$ & $\begin{array}{l}\text { Computerized } \\
\text { tomography }\end{array}$ \\
\hline $\begin{array}{l}\text { Manhein and } \\
\text { Listi }\end{array}$ & 2000 & 19 & & & 712 & American & Ultrasound \\
\hline $\begin{array}{l}\text { El- } \\
\text { Mehallawi } \\
\text { and Soliman }\end{array}$ & 2001 & 17 & 120 & 84 & 204 & $\begin{array}{l}\text { Egyptian } \\
\text { (Living) }\end{array}$ & Ultrasound \\
\hline $\begin{array}{l}\text { El- } \\
\text { Mehallawi } \\
\text { and Soliman }\end{array}$ & 2001 & 17 & 120 & 84 & 204 & Egyptian & Ultrasound \\
\hline Sahni & 2002 & 19 & 30 & 30 & 60 & Indians (Living) & MRI scans \\
\hline $\begin{array}{l}\text { Simpson and } \\
\text { Henneberg }\end{array}$ & 2002 & 20 & 17 & 23 & 40 & Australian & $\begin{array}{l}\text { Tissue punc- } \\
\text { ture by using } \\
\text { needle }\end{array}$ \\
\hline Wilkinson & 2002 & 21 & 99 & 101 & 200 & $\begin{array}{l}\text { British } \\
\text { Juveniles }\end{array}$ & $\begin{array}{l}\text { Ultrasonic } \\
\text { echo-location }\end{array}$ \\
\hline $\begin{array}{l}\text { Williamson } \\
\text { and } \\
\text { Nawrocki }\end{array}$ & 2002 & 15 & 77 & 147 & 224 & $\begin{array}{l}\text { African } \\
\text { American }\end{array}$ & X-Ray \\
\hline $\begin{array}{l}\text { Utsuno and } \\
\text { Kageyama }\end{array}$ & 2005 & 12 & 0 & 112 & 112 & Japanese & X-Ray \\
\hline
\end{tabular}


Table 3.4 (continued)

\begin{tabular}{|c|c|c|c|c|c|c|c|}
\hline Reference & Date & $\begin{array}{l}\text { Number } \\
\text { of points }\end{array}$ & Male & Female & Total & Population $^{\mathrm{a}}$ & Methods \\
\hline $\begin{array}{l}\text { De Greef } \\
\text { et al. }\end{array}$ & 2006 & 52 & 510 & 457 & 967 & $\begin{array}{l}\text { White Cauca- } \\
\text { sian (Living) }\end{array}$ & Ultrasound \\
\hline $\begin{array}{l}\text { Domaracki } \\
\text { and Stephan }\end{array}$ & 2006 & 13 & 19 & 14 & 33 & Australian & $\begin{array}{l}\text { Tissue punc- } \\
\text { ture by using } \\
\text { needle }\end{array}$ \\
\hline $\begin{array}{l}\text { Vander } \\
\text { Pluym et al. }\end{array}$ & 2007 & - & 5 & 5 & 10 & $\begin{array}{l}\text { American (mul- } \\
\text { tiple ancestries) }\end{array}$ & MRI \\
\hline Panenková & 2007 & 14 & 80 & 80 & 160 & Slovak & CT Scan \\
\hline $\begin{array}{l}\text { Galdames } \\
\text { et al. }\end{array}$ & 2008 & 14 & 30 & & 30 & Cadavers & $\begin{array}{l}\text { Tissue punc- } \\
\text { ture by using } \\
\text { needle }\end{array}$ \\
\hline Sahni et al. & 2008 & 29 & 173 & 127 & 300 & Indian & MRI \\
\hline Inada et al. & 2009 & & 40 & 40 & 80 & $\begin{array}{l}\text { Mongoloid } \\
\text { (Japanese) } \\
\text { (Living) }\end{array}$ & Cephalograms \\
\hline $\begin{array}{l}\text { Codinha and } \\
\text { Fialho }\end{array}$ & 2010 & 20 & 103 & 48 & 151 & Portuguese & $\begin{array}{l}\text { Tissue punc- } \\
\text { ture by using } \\
\text { needle }\end{array}$ \\
\hline $\begin{array}{l}\text { Menezes } \\
\text { et al. }\end{array}$ & 2009 & 50 & 531 & 357 & 888 & & $\begin{array}{l}\text { Electronic } \\
\text { digitizer }\end{array}$ \\
\hline $\begin{array}{l}\text { Tedeschi- } \\
\text { Oliveira et al. }\end{array}$ & 2009 & 11 & 26 & 14 & 40 & Brazilian & $\begin{array}{l}\text { Tissue punc- } \\
\text { ture by using } \\
\text { needle }\end{array}$ \\
\hline $\begin{array}{l}\text { Cavanagh } \\
\text { and Steyn }\end{array}$ & 2011 & 28 & 0 & 154 & 154 & South African & CT Scan \\
\hline Saxena et al. & 2012 & 7 & 19 & 21 & 40 & Indian & CT Scan \\
\hline Hwang et al. & 2012 & 31 & 50 & 50 & 100 & Korean & CT Scan \\
\hline
\end{tabular}

${ }^{a}$ Population as described by the authors

Other factors that must be taken into account when utilizing soft tissue data are growth, weight change, and age-related changes. For this purpose, many authors place emphasis on facial features with minimal soft tissue depth. The middle third of the face (eyes, nose, and teeth) is less influenced by any photographic distortion and could be considered more accurate (Taylor and Brown 1998).

Currently, there is no agreement among practitioners as to the number of landmarks, their name, or their correct position; thus, comparison between the results of several papers is extremely difficult (Panenková 2007). Furthermore, some papers use the vernacular rather than anatomical terminology, that is, "end of nasal" (Phillips and Smuts 1996), "middle of the bony nose" (Helmer 1984), and "angle of mouth" (Aulsebrook et al. 1996; Panenková 2007).

There seems to be one major difference of opinion with regard to the thicknesses of facial tissues (Wilkinson 2002). The results obtained by the needle puncture method in cadavers are relative to the process of dehydration of the soft tissue (10-18 g/day/weight), resulting in considerable variations depending on the 
Table 3.5 Comparison of the commonly used measuring techniques for calculating soft-tissue depth

\begin{tabular}{|c|c|c|}
\hline $\begin{array}{l}\text { Method of } \\
\text { measurement }\end{array}$ & Advantage & Disadvantage \\
\hline Needle puncture & $\begin{array}{l}\text { Low cost. } \\
\text { Operating characteristics well } \\
\text { defined. Measurements can be made } \\
\text { in Frankfort. Horizontal plane. }\end{array}$ & $\begin{array}{l}\text { Invasive. } \\
\text { Most information from cadavers, } \\
\text { soft tissue may not accurately } \\
\text { reflect living tissue. } \\
\text { Compression of soft tissue inevita- } \\
\text { ble during measurement. } \\
\text { No visualization of the skeletal } \\
\text { surface. }\end{array}$ \\
\hline $\begin{array}{l}\text { Plain film } \\
\text { radiography }\end{array}$ & $\begin{array}{l}\text { Standard cephalograms widely used } \\
\text { in dentistry and medicine. } \\
\text { Films generally taken in Frankfort } \\
\text { horizontal plane. Relatively inex- } \\
\text { pensive. } \\
\text { No compression of tissue while tak- } \\
\text { ing measurement. }\end{array}$ & $\begin{array}{l}\text { Exposure to ionizing radiation, } \\
\text { patient selection may bias results. } \\
\text { Only useful where surface land- } \\
\text { mark and bony landmark are par- } \\
\text { allel to the film plate. } \\
\text { Metallic implants (braces and fill- } \\
\text { ings) may interfere with measure- } \\
\text { ments. Magnification issues. }\end{array}$ \\
\hline $\begin{array}{l}\text { Computerized } \\
\text { tomography }\end{array}$ & $\begin{array}{l}\text { Widely used in medicine and den- } \\
\text { tistry. } \\
\text { Images are digital and easy to } \\
\text { manipulate (e.g., absorption charac- } \\
\text { teristic of soft and hard tissue rela- } \\
\text { tively easy to distinguish). } \\
\text { Accuracy of surface landmark } \\
\text { placement relative to bony landmark } \\
\text { can be verified. } \\
\text { Paired landmarks easily measured. } \\
\text { Known accuracy and } \\
\text { reproducibility. }\end{array}$ & $\begin{array}{l}\text { Expensive. } \\
\text { Requires exposure to ionizing } \\
\text { radiation, patient selection may } \\
\text { introduce bias. } \\
\text { Patient motion artifact (voluntary } \\
\text { or involuntary) may interfere with } \\
\text { measurements. } \\
\text { Radio-opaque objects (e.g., filling, } \\
\text { braces) may distort images and } \\
\text { measurements. } \\
\text { Images are not in Frankfort hori- } \\
\text { zontal plane. } \\
\text { Gravity effects on soft tissue due to } \\
\text { supine position. } \\
\text { Translation to 3D shape may } \\
\text { involve manual intervention. }\end{array}$ \\
\hline $\begin{array}{l}\text { Magnetic } \\
\text { Resonance Imaging }\end{array}$ & $\begin{array}{l}\text { No exposure to ionizing radiation, } \\
\text { ethically acceptable to image sub- } \\
\text { jects for tissue depth estimation. } \\
\text { Can be repeated on same subjects to } \\
\text { obtain longitudinal data. } \\
\text { No soft-tissue compression during } \\
\text { measurement } \\
\text { Images are digital and easy to } \\
\text { manipulate (e.g. absorption charac- } \\
\text { teristics of soft and hard tissue rela- } \\
\text { tively easy to distinguish). } \\
\text { Accuracy of surface landmark } \\
\text { placement relative to bony landmark } \\
\text { can be verified. } \\
\text { Paired landmarks easily measured. }\end{array}$ & $\begin{array}{l}\text { Very expensive. } \\
\text { Images generally not acquired in } \\
\text { Frankfort horizontal plane. } \\
\text { Requires exposure to high-intensity } \\
\text { magnetic field, subjects with } \\
\text { metallic exposure not eligible. } \\
\text { Subject motion artifact distorts } \\
\text { images. } \\
\text { May not visualize bone well. } \\
\text { Gravity effects due to supine posi- } \\
\text { tion. } \\
\text { Translation to 3D shape may } \\
\text { involve manual intervention. }\end{array}$ \\
\hline
\end{tabular}


Table 3.5 (continued)

\begin{tabular}{|c|c|c|}
\hline $\begin{array}{l}\text { Method of } \\
\text { measurement }\end{array}$ & Advantage & Disadvantage \\
\hline Ultrasound & $\begin{array}{l}\text { No exposure to ionizing radiation; } \\
\text { can be used repeatedly in the same } \\
\text { subject. } \\
\text { Portable, can be used in the field. } \\
\text { Measurements made in Frankfort } \\
\text { horizontal plane. }\end{array}$ & $\begin{array}{l}\text { Probe must touch skin surface, tis- } \\
\text { sue compression possible with } \\
\text { inexperienced operator. } \\
\text { Operating characteristics of porta- } \\
\text { ble equipment differ according to } \\
\text { manufacturer and must be defined } \\
\text { before use. } \\
\text { Difficult to scan parallel to skeletal } \\
\text { surface and this can make visuali- } \\
\text { zation of the surface more } \\
\text { challenging. }\end{array}$ \\
\hline
\end{tabular}

Taken from Taylor and Brown (1998)

Table 3.6 Systematic bias of soft-tissue measurement according to method of measurements

\begin{tabular}{l|l|l|l}
\hline $\begin{array}{l}\text { Measurement } \\
\text { technique }\end{array}$ & $\begin{array}{l}\text { Landmarks at which tissue } \\
\text { depths are consistently } \\
\text { higher than with other } \\
\text { techniques }\end{array}$ & $\begin{array}{l}\text { Landmarks at which tissue } \\
\text { depths are consistently } \\
\text { lower than with other } \\
\text { techniques }\end{array}$ & $\begin{array}{l}\text { Measurements } \\
\text { technique that } \\
\text { most closely } \\
\text { correlates }\end{array}$ \\
\hline $\begin{array}{l}\text { Needle } \\
\text { puncture }\end{array}$ & - & - & - \\
\hline $\begin{array}{l}\text { Plain } \\
\text { radiology }\end{array}$ & All midline landmarks & $\begin{array}{l}\text { Lateral landmarks: gonion } \\
\text { and zygion }\end{array}$ & - \\
\hline CT scan & All midline landmarks & All midline points & MRI \\
\hline MRI scan & - & All midline points & CT \\
\hline Ultrasound & $\begin{array}{l}\text { Supra M2, infra M2, gonion, } \\
\text { mid-infraorbital, anterior } \\
\text { masseter border }\end{array}$ & - & $\begin{array}{l}\text { Needle puncture } \\
\text { (except for supra } \\
\text { M2) }\end{array}$ \\
\hline
\end{tabular}

Taken from Preedy (2012)

different methods used for conservation, alongside the development of rigor mortis, which affects the muscle fibers (Galdames et al. 2008; de Greef et al. 2006).

Various investigators have compared the soft facial tissue thicknesses measured in fresh cadavers with embalmed cadavers. Simpson and Henneberg (2002) reported an increase in soft tissue thickness of all landmarks, due to embalming processes. Galdames et al. (2008) indicated that the embalmed cadavers presented larger thicknesses of tissue in all sites, with the exception of the right exocanthion and right and left gonion points. The most significant differences between fresh and embalmed tissue were observed at the trichion, glabella, nasion, pogonion, superciliary, supraorbital, infraorbital, and gonion points (Galdames et al. 2008; Simpson and Henneberg 2002).

Postmortem data and the use of the different methods of cadaver conservation must be considered when comparing measurements with those obtained from living subjects by means of radiograph, ultrasound, computerized tomography, or nuclear magnetic resonance (Clement and Ranson 1998; Galdames et al. 2008). 


\subsection{Anatomical Relationships}

The face is one of the most individualistic and unique parts of the human body. It is important to establish the most commonly utilized morphological features when carrying out an assessment of face and skull correspondence. There are many standards for the prediction of the soft tissue features from skeletal assessment, and these standards were established through human dissection, palpation, medical imaging modalities, and direct anthropometry of living subjects. The relative limitations of each method when evaluating the reliability of the standards produced should be noted. Human dissection studies offer a unique opportunity to visualize the face and the related skeletal structures, but are limited by the effects of embalming, deformation associated with a cadaver face, and dehydration. Palpation studies employ living faces but are limited by the inability to accurately locate bony landmarks, especially in the areas of the face with the greatest soft tissues. Clinical imaging of living faces enables the visualization of soft and hard tissues simultaneously, but different imaging modalities suffer from gravitational problems (the subject is supine), artifacts (dental flare), bone visibility (MRI), and pressure effects (ultrasound). Direct anthropometry from a living subject is probably the most reliable form of data collection, but although multiple measurements can be collected from the soft tissues, direct measurements of the skull are limited to the teeth.

This report will attempt to highlight the published anatomical standards feature by feature.

\subsubsection{General Face Shape}

The relationship between the shape of the head and the shape of the cranium is well established. Several classifications of this relationship have been published (Clement and Ranson 1998; Fedosyutkin and Nainys 1993; Balueva et al. 2009), Table 3.7 summarizes the standards.

The relationship between facial measurements and related skull measurements has also been studied (Balueva et al. 2009). Table 3.8 summarizes the standards.

\subsubsection{The Eyebrows}

Eyebrow pattern standards (Table 3.9) have been developed from a combination of palpation (Balueva et al. 2009) and craniograph studies (Fedosyutkin and Nainys 1993). 
Table 3.7 Shape relationships of head and cranium

\begin{tabular}{|c|c|}
\hline $\begin{array}{l}\text { Morphological and } \\
\text { facial traits }\end{array}$ & Correspondence with facial structures \\
\hline \multicolumn{2}{|c|}{ The general head shape } \\
\hline Shape of face & Transverse arc of the cranium \\
\hline Rounded & Semisphere \\
\hline Square & Pentagonoid \\
\hline Oval & Oval \\
\hline \multirow[t]{2}{*}{ Triangular } & Rectangular \\
\hline & $\begin{array}{l}\text { The shape of the temporal lines provides information about the forehead } \\
\text { width }\end{array}$ \\
\hline Shape of the face & Mandible \\
\hline Oval & $\begin{array}{l}\text { If the gonial angle is over } 125^{\circ} \text { and the coronoid process is high, the } \\
\text { lowest part of the head is likely to be narrow }\end{array}$ \\
\hline Triangular & $\begin{array}{l}\text { If the gonial angle is over } 125^{\circ} \text { and the coronoid process is high, the } \\
\text { lowest part of the head is likely to be narrow }\end{array}$ \\
\hline Rounded & $\begin{array}{l}\text { If the gonial angle is less than } 125^{\circ} \text {, then the face shape is likely to be } \\
\text { wide }\end{array}$ \\
\hline Rectangular & $\begin{array}{l}\text { If the gonial angle is less than } 125^{\circ} \text {, then the face shape is likely to be } \\
\text { wide }\end{array}$ \\
\hline \multicolumn{2}{|l|}{ General face shape } \\
\hline Rounded & $\begin{array}{l}\text { Parietal part gently curved in frontal view; occiput rounded in lateral } \\
\text { view }\end{array}$ \\
\hline Dome shaped & Parietal part protruding; occiput flattened in lateral view \\
\hline Egg shaped & Parietal part gently curved in frontal view; occiput protruding \\
\hline Keel shaped & $\begin{array}{l}\text { Parietal part narrow, laterally compressed and "sharpened" in frontal } \\
\text { view; gently curved or protruding in lateral view; occiput rounded, } \\
\text { flattened, or protruding }\end{array}$ \\
\hline Flattened & $\begin{array}{l}\text { Parietal part flattened in frontal view, flattened in lateral view; occiput } \\
\text { rounded or protruding in lateral view }\end{array}$ \\
\hline Saddle shape & $\begin{array}{l}\text { Parietal part gently curved or flattened, saddle shaped in lateral view; } \\
\text { occiput rounded, flattened, or protruding in lateral view }\end{array}$ \\
\hline \multicolumn{2}{|l|}{ Face in frontal view } \\
\hline Rounded & As in cranial contour; malar bones prominent; general contour rounded \\
\hline Oval & As in cranial contour; facial outline smooth; general contour elliptical \\
\hline Triangular & $\begin{array}{l}\text { As in cranial contour; frontal part wide, mandible narrow; general } \\
\text { contour triangular }\end{array}$ \\
\hline Square & $\begin{array}{l}\text { As in cranial contour; transverse dimensions large; general contour } \\
\text { square }\end{array}$ \\
\hline Rectangular & $\begin{array}{l}\text { As in cranial contour; frontal and mandibular widths roughly equal; face } \\
\text { high, outline angular; general contour rectangular }\end{array}$ \\
\hline Diamond-shaped & $\begin{array}{l}\text { As in cranial contour; frontal and mandibular breadth small, face broad } \\
\text { and high; general contour diamond shaped }\end{array}$ \\
\hline \multicolumn{2}{|l|}{ Vertical facial profile } \\
\hline Sharp & Nasal saddle high; malar bones not prominent \\
\hline Flattened & Nasal saddle low; malar bones prominent \\
\hline
\end{tabular}


Table 3.7 (continued)

\begin{tabular}{|c|c|}
\hline $\begin{array}{l}\text { Morphological and } \\
\text { facial traits }\end{array}$ & Correspondence with facial structures \\
\hline \multicolumn{2}{|c|}{ Frontal curvature in profile } \\
\hline Flat & Frontal outline nearly straight \\
\hline Convex & Frontal outline convex arc \\
\hline Concave & $\begin{array}{l}\text { Both glabella and frontal tubers developed, creating the impression of } \\
\text { concavity in the middle part }\end{array}$ \\
\hline Wavy & $\begin{array}{l}\text { Glabella developed, well-expressed flexure between it and the upper } \\
\text { part of the frontal bone }\end{array}$ \\
\hline \multicolumn{2}{|c|}{ Frontal angle in profile } \\
\hline Vertical & $\begin{array}{l}\text { Perpendicular to Frankfort horizontal plane tangent to glabella nearly } \\
\text { vertical }\end{array}$ \\
\hline Inclined backward & $\begin{array}{l}\text { Perpendicular to Frankfort horizontal plane tangent to glabella inclined } \\
\text { backward }\end{array}$ \\
\hline Inclined forward & $\begin{array}{l}\text { Perpendicular to Frankfort horizontal plane tangent to glabella inclined } \\
\text { forward }\end{array}$ \\
\hline \multicolumn{2}{|l|}{ Brow ridges } \\
\hline Medium & $\begin{array}{l}\text { Brow ridges markedly prominent, but without a depression between } \\
\text { them }\end{array}$ \\
\hline Large & Brow ridges markedly prominent and separated by depression \\
\hline Small & Brow ridges barely distinguishable \\
\hline \multicolumn{2}{|l|}{ Brow ridges } \\
\hline Medium & Moderately prominent from side view \\
\hline Large & Markedly prominent from side view \\
\hline Small & Barely distinguishable from side view \\
\hline \multicolumn{2}{|c|}{ Length of brow ridges } \\
\hline Large & Extend beyond midpoint of supraorbital margin \\
\hline Small & Do not reach midpoint of supraorbital margin \\
\hline
\end{tabular}

Table 3.8 Related face and skull measurements

\begin{tabular}{|c|c|}
\hline \multicolumn{2}{|c|}{ Relative facial breadth } \\
\hline Medium & $($ Bizygomatic $(45)+10 \mathrm{~mm}) /($ supraorbitale to gnathion $(47 \mathrm{~b})+6 \mathrm{~mm})=1.10 \pm 0.04$ \\
\hline Large & $($ Bizygomatic $(45)+10 \mathrm{~mm}) /($ supraorbitale to gnathion $(47 \mathrm{~b})+6 \mathrm{~mm})>1.14$ \\
\hline Small & $($ Bizygomatic $(45)+10 \mathrm{~mm}) /($ supraorbitale to gnathion $(47 \mathrm{~b})+6 \mathrm{~mm})<1.06$ \\
\hline \multicolumn{2}{|c|}{ Frontal height } \\
\hline Medium & $($ Trichion to supraorbitale)/(supraorbitale to gnathion $(47 \mathrm{~b})+6 \mathrm{~mm})=0.45 \pm 0.03$ \\
\hline Large & (Trichion to supraorbitale)/(supraorbitale to gnathion $(47 \mathrm{~b})+6 \mathrm{~mm})>0.48$ \\
\hline Small & (Trichion to supraorbitale)/(supraorbitale to gnathion $(47 \mathrm{~b})+6 \mathrm{~mm})<0.42$ \\
\hline \multicolumn{2}{|r|}{ Frontal breadth } \\
\hline Medium & $($ Bicoronal $(10)+10 \mathrm{~mm}) /($ bizygomatic $(45)+10 \mathrm{~mm})=0.90 \pm 0.02$ \\
\hline Large & $($ Bicoronal $(10)+10 \mathrm{~mm}) /($ bizygomatic $(45)+10 \mathrm{~mm})>0.92$ \\
\hline Small & $($ Bicoronal $(10)+10 \mathrm{~mm}) /($ bizygomatic $(45)+10 \mathrm{~mm})<0.88$ \\
\hline
\end{tabular}


Table 3.9 Eyebrow pattern standards

\begin{tabular}{l|l}
\hline Eyebrow pattern \\
\hline Overhanging & $\begin{array}{l}\text { There is a strong development of the supraorbital margin and brow ridge, the } \\
\text { eyebrows are shifted downward, 1-2 mm lower than the supraorbital rim }\end{array}$ \\
\hline Arched & $\begin{array}{l}\text { This is related to a smooth forehead and high orbit, with the eyebrow following } \\
\text { the curve of the supraorbital margin }\end{array}$ \\
\hline Triangular & $\begin{array}{l}\text { There is thickening of the outer part of the supraorbital rim and a strong brow } \\
\text { ridge, the eyebrow is arranged over the supraorbital margin forming an angle }\end{array}$ \\
\hline Outline of eyebrows \\
\hline Straight & Supraorbital margin straight; superciliary arch horizontal \\
\hline Arched & Supraorbital margin arcuate; lateral end of superciliary arch directed upward \\
\hline Broken & Supraorbital margin wavy; lateral end of superciliary arch directed upward \\
\hline
\end{tabular}

Table 3.10 Relationship between the eyeball and the orbit

\begin{tabular}{l|l}
\hline Eyes & \\
\hline Protrusion of the eyeballs \\
\hline Deep-set eye & $\begin{array}{l}\text { This is related to the depth of the orbital cavity, vertical inclination of the orbit, } \\
\text { and the thickness and degree of overhang of its upper rim }\end{array}$ \\
\hline $\begin{array}{l}\text { The supraorbital rim is greatly thickened and protrudes relative to the } \\
\text { infraorbital rim } \\
\text { Supraorbital margin projects inferiorly (“closed orbit") } \\
\text { (orbital height }(52)) /(\text { exocanthion to endocanthion) }<0.81\end{array}$ \\
\hline Prominent eye & $\begin{array}{l}\text { Supraorbital margin does not project inferiorly } \\
\text { (orbital height }(52)) /(\text { exocanthion to endocanthion) })\end{array}$ \\
\hline $\begin{array}{l}\text { Eyeball } \\
\text { prominence }\end{array}$ & $\begin{array}{l}\text { Normal prominence is when the iris touches a tangent across the } \\
\text { mid-supraorbital to mid-infraorbital bone } \\
\text { eyeball protrusion }=18.3-(0.4 \times \text { orbit depth) }\end{array}$ \\
\hline
\end{tabular}

\subsubsection{The Eyes}

A number of studies assessing the relationship between the eyeball and the orbit in relation to prominence and frontal position have been conducted.

Prominence studies utilizing MRI (Wilkinson and Mautner 2003) exophthalmometry (Stephan 2002), and palpation (Fedosyutkin and Nainys 1993; Balueva et al. 2009) all present results indicating a general agreement between current published standards (see Table 3.10).

Studies on the position of the eyeball in the orbit from a frontal view seem to report different results depending on the method of assessment. Dissection studies (Whitnall 1921; Stephan and Davidson 2008; Stephan et al. 2003) suggest that the eyeball sits slightly superior $(1-2 \mathrm{~mm})$ and lateral to the centre in the orbit, but palpation studies (Balueva and Veselovskaya 2004) suggest that the eyeball sits $2 \mathrm{~mm}$ closer to the medial wall than the lateral wall; other dissection studies (Krogman and İşcan 1986) suggest the eyeball sits centrally in the orbit. 
The positions of the inner (endocanthus) and outer (exocanthus) corners of the eye have been studied in detail, but there is no clear agreement between standards. There is a general agreement concerning the malar (or Whitnall's) tubercle in relation to the outer canthus. Human dissection has shown that the tendons that fix the eyelids to the orbit are inserted at this tubercle (Whitnall 1921). Although it has been established that the outer canthus is located at the same height as the malar tubercle, there is no consensus as to the distance of the outer canthus from the orbital wall. The distance has been published as $1 \mathrm{~mm}$ (Sills 2004), 3-5 mm (Balueva et al. 2009; Angel 1978; Krogman and İşcan 1986; Stephan 2009), 5-7 mm (Wolff 1976; Rosenstein et al. 2000), 8-10 mm (Couly et al. 1976), and $13 \mathrm{~mm}$ (Anastassov and van Damme 1996). Where the malar tubercle is absent, the outer canthus can be positioned 8-11 mm below the line of the frontozygomatic suture (Stewart 1983; Krogman and İscan 1986; Wolff 1976).

There is an agreement that the medial canthus is positioned approximately 2-5 mm lateral to the anterior lacrimal crest (Yoshino and Seta 1989; Angel 1978; Sills 2004; Krogman and İşcan 1986; Stephan 2009), but where exactly on the anterior lacrimal crest this measurement is taken from is unclear. Different studies suggest the top (Balueva and Veselovskaya 2004), middle (Angel 1978), and base (Fedosyutkin and Nainys 1993) as the measurement point, while other studies suggest that the point can be found 4-5 mm (Angel 1978) or $10 \mathrm{~mm}$ (Stewart 1983) below the dacryon. Table 3.11 presents the standards related to dissection and anthropometrical studies (Whitnall 1921; Merkel 1886).

Table 3.11 Position of the inner (endocanthus) and outer (exocanthus) corners of the eye

\begin{tabular}{l|l}
\hline Eyes & $\begin{array}{l}\text { The slope of the fissure is defined by a straight line that connects the malar (Whitnall's) } \\
\text { tubercle on the lateral border of the orbit with the anterior lacrimal crest on the medial } \\
\text { border of the orbit }\end{array}$ \\
\cline { 2 - 3 } & $\begin{array}{l}\text { The curves of the eyelid margins are not symmetrical and the upper lid is more } \\
\text { pronounced than the lower, its height being greatest nearer the medial angle, whereas } \\
\text { that of the lower lid is nearer the lateral angle } \\
\text { The lateral canthal angle is more acute than the medial and lies in close contact with the } \\
\text { globe, whereas the medial canthus extends toward the nose } 5-7 \text { mm away from the } \\
\text { globe, being separated by the caruncula and the plica semilunaris } \\
\text { The radius of the upper eyelid curve is } 16.5 \text { mm and that of the lower eyelid is } 22 \text { mm } \\
\text { The outer canthus (exocanthus) is positioned at the same height as the malar } \\
\text { (Whitnall's tubercle) and medial to it } \\
\text { Where the malar tubercle is absent, the outer canthus can be positioned } 8-11 \text { mm } \\
\text { below the line of the frontozygomatic suture } \\
\text { The inner canthus (endocanthus) is situated } 2-5 \text { mm lateral to the anterior lacrimal } \\
\text { crest }\end{array}$ \\
\hline Eye fissure & The length of the eye fissure is $60-80 \%$ of the width of the orbit \\
\hline Medium & $\begin{array}{l}\text { (Exocanthion to endocanthion }-14 \mathrm{~mm}) /(\text { upper facial breadth }(43) \\
+10 \text { mm) }=0.25 \pm 0.01\end{array}$ \\
\hline (Exocanthion to endocanthion $-14 \mathrm{~mm}) /($ upper facial breadth $(43)+10$ mm) $>0.26$ \\
\hline (Exocanthion to endocanthion $-14 \mathrm{~mm}) /($ upper facial breadth $(43)+10$ mm) $<0.24$ \\
\hline
\end{tabular}


Table 3.12 Eyelid pattern

\begin{tabular}{l|l}
\hline Eyelid patterns \\
\hline Lateral & There is an overhang in the lateral part of the supraorbital rim \\
\hline Central & There is an overhang in the central part of the supraorbital rim \\
\hline Upper eyelid fold \\
\hline Moderate & Supraorbital margins straight or slightly rounded \\
\hline Defined & Supraorbital margins arched and sharp \\
\hline Absent & Supraorbital margins arched, supraorbital overhang markedly shifted medially \\
\hline Irregular & Supraorbital margin wave shaped or oblique in distal part \\
\hline Epicanthic fold \\
\hline Present & $\begin{array}{l}\text { Crest descending from medial supraorbital margin directed toward anterior lacrimal } \\
\text { crest } \\
\text { This is characteristic of a high orbit, a low-or medium-height nasal bridge, and a long } \\
\text { lacrimal fossa }\end{array}$ \\
\hline Absent & Crest descending from medial supraorbital margin directed inside orbit \\
\hline
\end{tabular}

The eyelid pattern has been studied using palpation and anthropometry studies (comparison of skulls with ante-mortem images) (Balueva et al. 2009; Rynn et al. 2012). These standards are presented in Table 3.12.

\subsubsection{The Nose}

The nose is the most studied feature on the face; studies on the relationship between the configuration of the nasal tissue and the bones surrounding the nasal aperture are abundant (Gerasimov 1955; Macho 1986; McClintock Robinson et al. 1986; George 1993; Schultz 2005; Tandler 1909; Virchow 1912; Glanville 1969; Prokopec and Ubelaker 2002; Stephan et al. 2003). Studies conducted by Gerasimov (1955) show that the soft nose is wider than the bony aperture, as a narrower soft nose would have no supporting structure. Furthermore, he suggested that the bony nasal aperture at its widest point is three-fifths of the overall width of the soft nose. This assertion has been confirmed by a CT study on living subjects of various ethnic groups (Rynn 2006).

Gerasimov (1955) also suggested that the nasal base angle (the angle between the upper lip and the columella) is determined by the direction of the nasal spine. In his study, he stated that the axis of the nasal spine serves as a base for the soft nose and the determination of the nasal spine direction follows the point of the spine, as if it were an arrowhead. He also suggested that the end of the soft nose could be predicted as the point where a line following the projection of the last part of the nasal bones (at the rhinion) crosses a line following the direction of the nasal spine, and he confirmed these standards with a blind study of 50 cadaver heads. This standard has been widely debated in the literature; Ullrich, a former student of Gerasimov, claimed that Gerasimov did not follow the direction of the nasal spine, but rather the general direction of the floor of the anterior part of the nasal aperture (maxillary 
bone) laterally adjacent to the anterior nasal spine and vomer bone (Ullrich and Stephan 2011). However, this is disputed by the academic group who worked for many years alongside Gerasimov and Lebedinskaya, and continue their work at the Russian Academy of Sciences in Moscow (Balueva et al. 2009; Rynn et al. 2012) and they confirm that the nasal spine was indeed the feature used by Gerasimov to determine the nasal base angle. Rynn and Wilkinson (2006) tested six different methods of nose prominence prediction (Gerasimov 1955; Prokopec and Ubelaker 2002; Macho 1986; Stephan et al. 2003; George 1987; Krogman and İşcan 1986) in order to understand which method was the most accurate. This study found that the Gerasimov (1955) method performed with the most accuracy, while the Krogman and İşcan (1986) method performed poorly.

Rynn (2006) produced guidelines for nasal shape prediction, utilizing three cranial measurements that can be used to predict six soft nose measurements. These guidelines were tested in a blind study showing a high level of accuracy (Rynn et al. 2010).

Gerasimov (1955) also suggested that the height of the upper border of the alae is in line with the crista conchalis and the profile of the nose is a nonscaled mirror of the nasal aperture in profile. These standards have been confirmed using CT data of living subjects (Rynn 2006); this study additionally confirmed previous papers' suggestions that deviation of the nasal tip from the midline is associated with opposing nasal septum deviation (Selzter 1944; Gray 1965) and that nasal tip bifurcation is associated with a bifid nasal spine (Weaver and Bellinger 1946).

A recent dissection study suggested that the shape of the nasal aperture when viewed from posterior-anterior aspect is mirrored in the shape of the nasal tip (Davy-Jow et al. 2012). Standards for nose shape prediction are given in Table 3.13.

\subsubsection{The Mouth}

There are some anatomical standards relating to mouth shape, which have been confirmed in different populations and by a variety of methods of study (Stephan et al. 2003; Balueva et al. 2009; Stephan and Murphy 2008; Angel 1978; Krogman and İscan 1986). These are presented in Table 3.14.

Scientific literature from orthodontic and anatomical disciplines suggests that the form of the mouth is related to the occlusion of the teeth (Roos 1977; Rudee 1964; Koch et al. 1979; Waldman 1982; Holdaway 1983; Denis and Speidel 1987; Talass et al. 1987), the dental pattern (Subtelny 1959), and the facial profile (Gerasimov 1955). These are presented in Table 3.14.

\subsubsection{The Cheeks}

Studies demonstrating the relationship between the zygomatic bones, the canine fossa, and the soft cheeks are presented in Table 3.15 (Fedosyutkin and Nainys 1993; Balueva et al. 2009). 
Table 3.13 Standards for nose shape prediction

\begin{tabular}{|c|c|}
\hline \multicolumn{2}{|l|}{ Nose } \\
\hline \multicolumn{2}{|c|}{ Height of the nose } \\
\hline & This equals the distance from nasion to $1-2 \mathrm{~mm}$ below the nasal spine \\
\hline Medium & $($ Supraorbitale to subspinale)/(trichion to gnathion $+6 \mathrm{~mm})=0.32 \pm 0.015$ \\
\hline Large & $($ Supraorbitale to subspinale) $/($ trichion to gnathion $+6 \mathrm{~mm})>0.335$ \\
\hline Small & (Supraorbitale to subspinale)/(trichion to gnathion $+6 \mathrm{~mm})<0.305$ \\
\hline $\begin{array}{l}\text { Nasal } \\
\text { length }\end{array}$ & Europeans: nasion to prosthion $=0.74$ (bony nasion to subspinale) +3.5 \\
\hline $\begin{array}{l}\text { Nasal } \\
\text { length }\end{array}$ & $\begin{array}{l}\text { Nasion to pronasale }(\mathrm{mm}) \text { in nasion-prosthion plane }=0.9 \text { (bony nasion to } \\
\text { acanthion) }-2\end{array}$ \\
\hline $\begin{array}{l}\text { Nasal } \\
\text { height }\end{array}$ & $\begin{array}{l}\text { European females: nasion to subspinale }=0.63 \text { (bony nasion to subspinale })+17 \\
\text { European males: nasion to subspinale }=0.78 \text { (bony nasion to subspinale })+9.5\end{array}$ \\
\hline \multicolumn{2}{|c|}{ Width of the nose } \\
\hline & $\begin{array}{l}\text { This is defined between the midpoints of the canines or their alveoli } \\
\text { The maximum width of the nasal aperture is three-fifths }(3 / 5) \text { of the maximum width } \\
\text { of the soft nose }\end{array}$ \\
\hline Medium & Nasal breadth/(bizygomatic breadth $(45)+10 \mathrm{~mm})=0.25 \pm 0.01$ \\
\hline Large & Nasal breadth/(bizygomatic breadth $(45)+10 \mathrm{~mm})>0.26$ \\
\hline Small & Nasal breadth/(bizygomatic breadth $(45)+10 \mathrm{~mm})<0.24$ \\
\hline \multicolumn{2}{|c|}{ The base of the nose } \\
\hline Horizontal & Horizontal nasal spine \\
\hline Elevated & Up-turned nasal spine \\
\hline Prolapsed & Down-turned nasal spine \\
\hline \multicolumn{2}{|c|}{ The tip of the nose } \\
\hline Bifid & Bifurcated nasal spine \\
\hline $\begin{array}{l}\text { Nasal } \\
\text { depth }\end{array}$ & $\begin{array}{l}\text { Female; subspinale to pronasale }=0.5 \text { (bony rhinion to subspinale })+1.5 \text { male; } \\
\text { subspinale to pronasale }=0.4 \text { (bony rhinion to subspinale })+5\end{array}$ \\
\hline Pronasale & Anterior projection $(\mathrm{mm})$ perpendicular to nasion-prosthion plane $=0.83 \mathrm{Y}-3.5$ \\
\hline Pronasale & $\begin{array}{l}\text { Projection from subspinale in Frankfort horizontal plane }=0.93 \text { (bony rhinion to } \\
\text { subspinale) }-6\end{array}$ \\
\hline Deviated & $\begin{array}{l}\text { Deviation of nose is opposite to the deviation of the nasal septum and in the same } \\
\text { direction as the nasal spine (right or left) }\end{array}$ \\
\hline Wide & $\begin{array}{l}\text { Wider than the nose ridge. It is correlated with a short, wide, groovy, nasal spine and } \\
\text { low, wide nasal foramen }\end{array}$ \\
\hline Moderate & Equal to the width of the nose ridge \\
\hline Narrow & $\begin{array}{l}\text { It is correlated with a long, narrow, pronounced nasal spine and long, narrow nasal } \\
\text { foramen }\end{array}$ \\
\hline Rounded & $\begin{array}{l}\text { Length of anterior nasal spine equal to or smaller than width of its base; tip of spine } \\
\text { forming an obtuse angle }\end{array}$ \\
\hline Pointed & Length of anterior nasal spine larger than width of its base; tip of spine pointed \\
\hline \multicolumn{2}{|c|}{ Wing of the nose } \\
\hline & $\begin{array}{l}\text { The wing of the nose begins at the lateral edge of the piriform foramen at the level of } \\
\text { nasal spine } \\
\text { The height of the upper border of the alae is in line with the crista conchalis } \\
\text { An exposed nasal septum is characteristic of a crest-shaped base of the nose }\end{array}$ \\
\hline Medium & $($ Conchale to subspinale $) /($ supraorbitale to subspinale $)=0.21 \pm 0.02$ \\
\hline
\end{tabular}


Table 3.13 (continued)

\begin{tabular}{|c|c|}
\hline \multicolumn{2}{|l|}{ Nose } \\
\hline High & $($ Conchale to subspinale $) /($ supraorbitale to subspinale $)>0.23$ \\
\hline Low & $($ Conchale to subspinale) $/($ supraorbitale to subspinale $)<0.19$ \\
\hline Level & $\begin{array}{l}\text { Left and right conchale and left and right lower points of the piriform aperture } \\
\text { situated on the same level }\end{array}$ \\
\hline $\begin{array}{l}\text { Right } \\
\text { higher }\end{array}$ & Right conchale or right lower point of the piriform aperture higher than left \\
\hline $\begin{array}{l}\text { Left } \\
\text { higher }\end{array}$ & Left conchale or left lower point of the piriform aperture higher than right \\
\hline \multicolumn{2}{|c|}{ Nasal bridge depth } \\
\hline Medium & Sellion not much deeper than glabella to rhinion line \\
\hline Large & Sellion much deeper than glabella to rhinion line \\
\hline Small & Sellion on glabella to rhinion line \\
\hline \multicolumn{2}{|c|}{ Nasal bridge breadth } \\
\hline Medium & $\begin{array}{l}\text { (Minimal breadth of nasal bones at nasal saddle level }(57)+6 \mathrm{~mm}) /(\text { naso-gnathic } \\
\text { left to naso-gnathic right }+6 \mathrm{~mm})=0.85 \pm 0.04\end{array}$ \\
\hline Large & $\begin{array}{l}\text { (Minimal breadth of nasal bones at nasal saddle level }(57)+6 \mathrm{~mm}) /(\text { naso-gnathic } \\
\text { left to naso-gnathic right }+6 \mathrm{~mm})>0.89\end{array}$ \\
\hline Small & $\begin{array}{l}\text { (Minimal breadth of nasal bones at nasal saddle level }(57)+6 \mathrm{~mm}) /(\text { naso-gnathic } \\
\text { left to naso-gnathic right }+6 \mathrm{~mm})<0.81\end{array}$ \\
\hline \multicolumn{2}{|c|}{ Nasal saddle width } \\
\hline Medium & $\begin{array}{l}\text { (Naso-gnathic left to naso-gnathic right }+6 \mathrm{~mm}) /(\text { canine left to canine right) } \\
=0.38 \pm 0.03\end{array}$ \\
\hline Large & (Naso-gnathic left to naso-gnathic right $+6 \mathrm{~mm}) /($ canine left to canine right) $>0.41$ \\
\hline \multirow[t]{2}{*}{ Small } & (Naso-gnathic left to naso-gnathic right $+6 \mathrm{~mm}$ )/(canine left to canine right) $<0.35$ \\
\hline & $\begin{array}{l}\text { Nasal ridge index }=\text { minimal breadth of nasal bone } \times 100 / \text { anterior length of nasal } \\
\text { bone } \\
10-30=\text { narrow; } 30-45=\text { medium; } 45-75=\text { broad }\end{array}$ \\
\hline
\end{tabular}

\subsubsection{The Ear}

Although there have been some studies relating ear morphology to skeletal structure, this facial feature is understudied. Gerasimov (1955) considered the angle of ear to be parallel to the jaw line and stated that when the mastoid processes are directed downward (in the Frankfort Horizontal Plane), the earlobe will be attached (adherent to the soft tissue of the cheek), whereas, where the mastoid processes point forward, the ear lobe will be free. However, recent dissection studies disagree as to the reliability of these standards; Renwick (2012) confirmed that adherent ear lobes relate to downward pointing mastoid processes, while studies using CT data showed no relationship between these features (Guyomarc'h and Stephan 2012). The confirmed standards are presented in Table 3.16. 
Table 3.14 Anatomical standards relating to mouth shape

\begin{tabular}{|c|c|}
\hline \multicolumn{2}{|l|}{ Mouth } \\
\hline \multicolumn{2}{|l|}{ Width of the mouth } \\
\hline & $\begin{array}{l}\text { Equal to the distance between the mandibular second molars } \\
\text { Mouth corners positioned on radiating lines (perpendicular to the } \\
\text { palate arc) from the first premolar-canine junction } \\
\text { Intercanine distance }=75 \% \text { of overall mouth width } \\
\text { The distance between the first premolars equal to mouth width } \\
\text { Mouth corners positioned vertically below the infraorbital foramina }\end{array}$ \\
\hline Medium & $\begin{array}{l}\text { Estimated on regression equation mouth width/(bigonial } \\
\text { breadth }+20 \mathrm{~mm})=0.52 \pm 0.02\end{array}$ \\
\hline Large & $\begin{array}{l}\text { Estimated on regression equation mouth width/(bigonial } \\
\text { breadth }+20 \mathrm{~mm})>0.54\end{array}$ \\
\hline Small & $\begin{array}{l}\text { Estimated on regression equation mouth width/(bigonial } \\
\text { breadth }+20 \mathrm{~mm})<0.50\end{array}$ \\
\hline \multicolumn{2}{|l|}{ Position of the fissure } \\
\hline & $\begin{array}{l}\text { The closed fissure is positioned at the level of the upper edge of the } \\
\text { anterior teeth of the mandible } \\
\text { The open fissure is positioned at the mid-line of the maxillary } \\
\text { incisors }\end{array}$ \\
\hline \multicolumn{2}{|l|}{ Height of the lips } \\
\hline & $\begin{array}{l}\text { Approximately equal to the height of the enamel of the upper and } \\
\text { lower incisors } \\
\text { European: maximum upper lip height }(\mathrm{mm})=0.4+(0.6 \times \text { max. } \\
\text { maxillary tooth enamel height }) \\
\text { European: maximum lower lip height }(\mathrm{mm})=5.5+(0.4 \times \text { max. } \\
\text { mandibular tooth enamel height }) \\
\text { Indian subcontinent: maximum upper lip height } \\
(\mathrm{mm})=3.4+(0.4 \times \text { max. maxillary tooth enamel height }) \\
\text { Indian subcontinent: maximum lower lip height } \\
(\mathrm{mm})=6+(0.5 \times \text { max. mandibular tooth enamel height })\end{array}$ \\
\hline Medium & $\begin{array}{l}\text { (Subspinale to supradentale)/(supraorbitale to gnathion }(2)+6 \mathrm{~mm} \text { ) } \\
=0.12 \pm 0.011\end{array}$ \\
\hline High & $\begin{array}{l}\text { (Subspinale to supradentale)/(supraorbitale to gnathion }(2)+6 \mathrm{~mm}) \\
>0.131\end{array}$ \\
\hline Low & $\begin{array}{l}\text { (Subspinale to supradentale)/(supraorbitale to gnathion }(2)+6 \mathrm{~mm} \text { ) } \\
<0.109\end{array}$ \\
\hline \multicolumn{2}{|l|}{ Width of the philtrum } \\
\hline & $\begin{array}{l}\text { The width of the philtrum corresponds to the distance between the } \\
\text { midpoints of the upper central incisors }\end{array}$ \\
\hline \multicolumn{2}{|l|}{ Prognathism } \\
\hline $\begin{array}{l}\text { Overbite or maxillary } \\
\text { prognathism }\end{array}$ & The upper lip projects more anteriorly than the lower lip \\
\hline $\begin{array}{l}\text { An underbite or edge-to- } \\
\text { edge occlusion }\end{array}$ & The lower lip protrudes more anteriorly than the upper lip \\
\hline
\end{tabular}


Table 3.14 (continued)

\begin{tabular}{l|l}
\hline \multicolumn{2}{l}{ Mouth } \\
$\begin{array}{l}\text { Line between closed lips } \\
\begin{array}{l}\text { Arched (upward or } \\
\text { downward) }\end{array}\end{array}$ & $\begin{array}{l}\text { The direction of these lines generally coincides with the line } \\
\text { formed when the teeth are closed }\end{array}$ \\
\hline $\begin{array}{l}\text { Straight (upward or } \\
\text { downward) }\end{array}$ & \\
\hline \multicolumn{2}{l}{ Occlusion and malocclusion } \\
\hline Edge-to-edge bite & Upper and lower anterior teeth fitting together edge-to-edge \\
\hline Moderate overbite & Anterior upper teeth slightly projecting over lower ones \\
\hline Roof-shaped & Marked overbite \\
\hline Cornice-shaped bite & Marked maxillary and mandibular alveolar prognathism \\
\hline Stepwise & $\begin{array}{l}\text { Anterior mandibular teeth projecting anteriorly relative to anterior } \\
\text { maxillary teeth }\end{array}$ \\
\hline Gaping & $\begin{array}{l}\text { Anterior maxillary and mandibular teeth curved and not fitting } \\
\text { together }\end{array}$ \\
\hline Oblique & Some teeth fit together normally, others show malocclusion \\
\hline
\end{tabular}

Table 3.15 Relationship between the zygomatic bones, the canine fossa, and the soft cheeks

Horizontal profile of the face

\begin{tabular}{|c|c|}
\hline & The cheekbones define the width of the face and its horizontal profile \\
\hline & $\begin{array}{l}\text { The horizontal profile of the face depends on the width and height of the } \\
\text { curvature of the cheekbones, the depth of the canine fossae, and the } \\
\text { nasomalar and zygomaxillary angles }\end{array}$ \\
\hline \multicolumn{2}{|c|}{ Size of malar bones } \\
\hline Medium & $\begin{array}{l}\text { Malar bones medium width and gently inclined backward; (bizygomatic } \\
\text { breadth }(45)+10 \mathrm{~mm}) /(\text { minimal frontal breadth }(9)+10 \mathrm{~mm}) \\
=1.37 \pm 0.03\end{array}$ \\
\hline Large & $\begin{array}{l}\text { Malar bones wide and frontally positioned; (bizygomatic breadth } \\
(45)+10 \mathrm{~mm}) /(\text { minimal frontal breadth }(9)+10 \mathrm{~mm})>1.40\end{array}$ \\
\hline Small & $\begin{array}{l}\text { Malar bones narrow and inclined backward; (bizygomatic breadth } \\
(45)+10 \mathrm{~mm}) /(\text { minimal frontal breadth }(9)+10 \mathrm{~mm})<1.34\end{array}$ \\
\hline \multicolumn{2}{|l|}{ Smile line } \\
\hline & $\begin{array}{l}\text { The nose-cheek (nasolabial) fold extends from the upper edge of the } \\
\text { nostril toward the upper first molar }\end{array}$ \\
\hline \multicolumn{2}{|c|}{ Protrusion of the smile line } \\
\hline & $\begin{array}{l}\text { It depends on the depth of the following parts: } \\
\text { - The canine fossa } \\
\text { - The degree of horizontal face profiling } \\
\text { - The projection of the frontal surface of the cheekbones } \\
\text { - The presence or absence of teeth }\end{array}$ \\
\hline $\begin{array}{l}\text { Nose-cheek folds } \\
\text { pronounced }\end{array}$ & The canine fossae are deep, and profiling of the face is strong \\
\hline \multicolumn{2}{|c|}{ Depth of the canine fossa } \\
\hline Shallow & Up to $3 \mathrm{~mm}$ \\
\hline Moderate & Between 4 and $6 \mathrm{~mm}$ \\
\hline Deep & Over $6 \mathrm{~mm}$ \\
\hline
\end{tabular}


Table 3.16 Relationship between ear morphology and skeletal structure

\begin{tabular}{l|l}
\hline Ear & \multicolumn{2}{l}{ The tragus of the ear corresponds to the upper rim of the external auditory meatus } \\
\cline { 2 - 2 } & The height of the ear approximates the length of the nose \\
\hline Protrusion of the ear \\
\hline Upper & The supramastoid crest on the temporal bone is strongly developed and protrudes \\
\hline Lower & The outer surface of the mastoid process is rough \\
\hline Total & All these features are present \\
\hline Lobe of the ear \\
\hline $\begin{array}{l}\text { Lobe } \\
\text { attached }\end{array}$ & $\begin{array}{l}\text { The mastoid processes are directed downward when the skull is in the Frankfort } \\
\text { horizontal plane }\end{array}$ \\
\hline Lobe free & The mastoid points forward when the skull is in the Frankfort horizontal plane \\
\hline
\end{tabular}

\subsubsection{The Chin}

There are some standards relating the mental region of the mandible to chin shape (Balueva et al. 2009). These are presented in Table 3.17.

The facial proportions are an important element to understanding facial geometry. The aim of the facial proportion assessment is to establish the variation from the ideal dimensions of the human form. This, combined with anthropometric norms, gives information about facial features as a symmetrical and balanced pattern, based on statistical means taking into account variations in age, sex, and ancestry. In this way, George (1993) described facial proportions based on the studies of Farkas and Munro (1987), Powell and Humphreys (1984).

\subsection{Examination Criteria for Craniofacial Superimposition}

Assessment of the quality of the matching and anatomical consistency between the face and skeletal structures for CFS has been carried out following a number of different criteria. These include the works of Helmer (1987), Helmer et al. (1989), Powell and Humphreys (1984), Chai et al. (1989), Austin-Smith and Maples (1994), Yoshino et al. (1995), Yoshino (2012), Lan (1995), Jayaprakash et al. (2001), Ricci et al. (2006), Ishii et al. (2011), and Gordon and Steyn (2012). These criteria are presented in detail below.

\subsubsection{Helmer $(1984,2012)$}

This method of assessment includes the use of several soft tissue thickness markers, attached to the skull along a vertical central line. Helmer employed average German 
Table 3.17 Relationship between the mental region of the mandible and chin shape

\begin{tabular}{l|l}
\hline & $\begin{array}{l}\text { The presence of convexities in the lower part of the mandibular body is a notable } \\
\text { feature both of the skull and of the face. }\end{array}$ \\
\hline Width of the chin & $\begin{array}{l}\text { This is defined by the degree of elevation in the mental region of the mandible and } \\
\text { the width its base. }\end{array}$ \\
\hline \multicolumn{2}{|l}{ Shape of the chin } \\
\hline High & The height of the mandibular body diminishes from the chin triangle to the rami. \\
\hline Wide & $\begin{array}{l}\text { Everted gonial regions of the mandible are associated with the wider variants of the } \\
\text { lower face and more developed masseter muscles. }\end{array}$ \\
\hline Height of the chin \\
\hline Medium & $\begin{array}{l}\text { (Supramentale to gnathion }+6 \text { mm }) /(\text { supraorbitale to } \\
\text { gnathion }+6 \text { mm) }=0.215 \pm 0.015\end{array}$ \\
\hline Large & (Supramentale to gnathion +6 mm)/(supraorbitale to gnathion $+6 \mathrm{~mm})>0.23$ \\
\hline Small & (Supramentale to gnathion +6 mm)/(supraorbitale to gnathion $+6 \mathrm{~mm})<0.20$ \\
\hline & $\begin{array}{l}\text { Chin height index }=\text { Height of the chin triangle } \times 100 / \text { Height of the ramus along the } \\
\text { second premolar } \\
100-110=\text { normal; } 110-115=\text { high; } 115-120=\text { very high }\end{array}$ \\
\hline Chin prominence \\
\hline Straight & Most projecting point of chin slightly anterior to vertical line \\
\hline Prominent & Most projecting point of chin markedly anterior to vertical line \\
\hline Receding & Most projecting point of chin on vertical line or behind it \\
\hline Width of the chin \\
\hline Medium & (Mentale left to mentale right)/(bigonial width +20 mm) $=0.35 \pm 0.02$ \\
\hline Large & (Mentale left to mentale right)/(bigonial width $+20 \mathrm{~mm})>0.37$ \\
\hline Small & (Mentale left to mentale right)/(bigonial width $+20 \mathrm{~mm})<0.33$ \\
\hline Shape of the chin in frontal view \\
\hline Rounded & Outline rounded, genial tubercles unexpressed \\
\hline Triangular & Outline pointed, genial tubercles close together \\
\hline Square & Outline square, genial tubercles wide apart \\
\hline
\end{tabular}

soft tissue data (Helmer 1984) collected by ultrasound. These cephalometric landmarks (nasion, rhinion, gonion, gnathion) are then matched to the profile on the antemortem photograph. The alignment of these landmarks indicates a positive identification. Variations on this methodology have been employed. Bajnóczky and Királyfalvi (1995) suggested a digital method to mark the superimposed antemortem photograph and skull image. The coordinate values of these points were then recorded and expressed as pixel units. Birngruber et al. (2010) glued 53 markers to the skull to mark the tissue depth at each anthropological landmark (Helmer 1984). The skull and the ante-mortem photograph were then superimposed in order to assess whether or not the tissue markers matched with the contours of the face. 
Table 3.18 Landmarks, lines, and profile curves suggested by Chai et al. (1984)

\begin{tabular}{l|l|l|l}
\hline Landmarks on face and skull & Facial lines & Skeletal lines & Profile outlines \\
\hline g: glabella & ex-ex & ec-ec & Cranial vault \\
\hline tr: trichion & g-gn & g-gn & Brow ridge \\
\hline v: vertex & se-se & se-se & Nasal \\
\hline n: nasion & ch-ch & -gn- & Gonial angle \\
\hline sn: subnasal & en-eh & & Lower jaw \\
\hline gn: gnathion & en-eh & & Occipital \\
\hline pg: pogonion & -gn- & & Forehead \\
\hline rhi: rhinion & & & Chin \\
\hline ns: nasospinale & & & Zygomatic \\
\hline pr: prosthion & & & \\
\hline inf: infradentale anterior & & & \\
\hline t: tragion & & & \\
\hline eu: euryon & & & \\
\hline al: alare & & & \\
\hline che: cheilion & & & \\
\hline en: endocanthion & & & \\
\hline ex: exocanthion & & & \\
\hline zy: zygion & & & \\
\hline go: gonion & & & \\
\hline ca: caninion & & & \\
\hline se: superciliary & & & \\
\hline ec: ectoconchion & & & \\
\hline
\end{tabular}

\subsubsection{Chai et al. (2010)}

This method is based on a study of 224 Chinese subjects (100 males and 124 females) aged between 18 and 55 years, from X-ray images. The protocol relies on the analysis of positional relationships between homologous facial and skull landmarks, the thickness of soft tissue at specific points, and the fit of facial outlines with the cranial structures. Fifty-two indices were established as a standard for CFS and identification (Table 3.18).

\subsubsection{Austin-Smith and Maples (1994)}

Two sets of 12 criteria are employed in this method to analyze skull-face consistency using lateral and frontal view photographs. Relevant soft tissue thickness data is also utilized along with the anatomical criteria. The authors suggest that with anterior dentition, skull/photograph superimposition is reliable when two or more photographs are used in the identification. The following features were used for a consistent fit between skull and face: 


\section{Lateral View}

1. The vault of the skull and the head height must be similar.

2. The glabellar outline of both the bone and the soft tissue must have a similar slope, although the line of the face does not always follow the line of the skull exactly. There may be slight differences in soft tissue thicknesses that do not relate to nuances in the contour of the bone.

3. The lateral angle of the eye lies within the bony lateral wall of the orbit.

4. The glabella, nasal bridge, and nasal bone area is perhaps the most distinctive. The prominence of the glabella and the depth of the nasal bridge are closely approximated by the soft tissue covering this area. The nasal bones fall within the structure of the nose and the imaginary continued line, composed of the lateral nasal cartilages in life, will conform to the shape of the nose except in cases of noticeable deformity.

5. The outline of the frontal process of the zygomatic bones can normally be seen in the flesh of the face. The skeletal process can be aligned with the process seen in the face.

6. The outline of the zygomatic arch can be seen and aligned in those individuals with minimal soft tissue thickness.

7. The anterior nasal spine lies posterior to the base of the nose near the most posterior portion of the lateral septal cartilage.

8. The porion aligns posterior to the tragus and inferior to the crus of the helix.

9. The prosthion lies posterior to the anterior edge of the upper lip.

10. The pogonion lies posterior to the indentation observable in the chin where the orbicularis oris muscle crosses the mentalis muscle.

11. The mental protuberance of the mandible lies posterior to the point of the chin. The shape of the bone (pointed or rounded) corresponds to the shape of the chin.

12. The occipital curve lies within the outline of the back of the head. This area is usually covered with hair and the exact location may be difficult to judge.

\section{Frontal View}

1. The length of the skull from bregma to menton fits within the face. Bregma is usually covered with hair.

2. The width of the cranium fills the forehead area of the face.

3. The temporal line can sometimes be distinguished on the photograph. If so, the line of the skull corresponds to the line seen on the face.

4. The eyebrow generally follows the upper edge of the orbit over the medial two-thirds. At the lateral superior one-third of the orbit, the eyebrow continues horizontally as the orbital rim begins to curve inferiorly.

5. The orbits completely encase the eyes including the medial and lateral folds. The point of attachment of the medial and lateral palpebral ligaments can usually be found on the skull. These areas align with the folds of the eye.

6. The lacrimal groove can sometimes be distinguished on the photograph. If so, the groove observable on the bone aligns with the groove seen on the face. 
7. The breadth of the nasal bridge on the cranium and surrounding soft tissue is similar. In the skull, the bridge extends from one orbital opening to the other. In the face, the bridge spreads between the medial palpebral ligament attachments.

8. The external auditory meatus opening lies medial to the tragus of the ear. The best way to judge this area is to place a projecting marker in the ear canal. On superimposition, the marker will appear to exit the ear behind the tragus.

9. The width and length of the nasal aperture falls inside the borders of the nose.

10. The anterior nasal spine lies superior to the inferior border of the medial crus of the nose. With advanced age, the crus of the nose begins to sag and the anterior nasal spine is located more superiorly.

11. The oblique line of the mandible (between the buccinator and the masseter muscles) is sometimes visible in the face. The line of the mandible corresponds to the line of the face.

12. The curve of the mandible is similar to that of the facial jaw. At no point does the bone appear to project from the flesh. Rounded, pointed, or notched chins will be evident in the mandible.

\subsubsection{Yoshino et al. $(1995,2012)$}

This method evaluates the anatomical consistency between skull and face by means of video superimposition. The anatomical relationships and soft tissue thickness data is based on Ogawa's data (Ogawa 1960). The exact thicknesses of soft tissue at the anthropometrical points of the skull are measured on the superimposed transparent films by using a sliding caliper. Eighteen assessment criteria are used for the evaluation of the anatomical consistency between the face and the skull. The criteria used are divided into three types: outlines, soft-tissue thickness, and positional relationships (Tables 3.19, 3.20, and 3.21). The authors suggest a positive identification can be achieved if 13 or more criteria demonstrate concordance between the skull and the face.

\subsubsection{Lan (1995)}

This method is based on a study of 3123 subjects from 15 nationalities (1554 males and 1569 females), with one front view and one profile photograph of each subject. The method includes anthropometry from photographs and X-rays. A total of 69 indices are established for identification (Table 3.22). The authors noted that some indices showed significant differences between different nationalities: the distance between the vertical line of ectocanthion and gonion; the distance between gonions; and the thickness of the soft tissue at the trichion, opisthocranion, and sellion. 
Table 3.19 Examination criteria for the assessment of anatomical consistency between the skull and the face

\begin{tabular}{|c|c|c|}
\hline Outline & $\begin{array}{l}\text { Soft tissue } \\
\text { thickness }\end{array}$ & Positional relationships \\
\hline $\begin{array}{l}\text { 1. Forehead } \\
\text { line }\end{array}$ & 1. Zygion & $\begin{array}{l}\text { 1. Distance from the supraorbital margin to the midline of } \\
\text { eyebrow }\end{array}$ \\
\hline 2. Buccal line & 2. Gnathion & 2. Distance from the medial orbital margin to the endocanthion \\
\hline $\begin{array}{l}\text { 3. Mandibu- } \\
\text { lar line }\end{array}$ & 3. Pogonion & 3. Distance from the lateral orbital margin to the ectocanthion \\
\hline $\begin{array}{l}\text { 4. Nasal dor- } \\
\text { sum line }\end{array}$ & 4. Gonion & $\begin{array}{l}\text { 4. Eye-slit standard ratio (eye-slit height from the lower orbital } \\
\text { margin/orbital height) }\end{array}$ \\
\hline- & 5. Nasion & 5. Distance from the lateral margin of nasal aperture to the ala \\
\hline- & 6. Rhinion & $\begin{array}{l}\text { 6. Distance from the lower margin of nasal aperture to the lowest } \\
\text { portion of external nasal tip }\end{array}$ \\
\hline- & 7. Subnasale & 7. Placement of the cheilion to upper teeth \\
\hline
\end{tabular}

Taken from Yoshino et al. (1995)

Table 3.20 Criteria for assessing anatomical consistency between skull and face in frontal view

\begin{tabular}{|c|c|c|c|c|c|}
\hline \multicolumn{2}{|l|}{ Outline } & \multicolumn{2}{|c|}{ Soft-tissue thickness } & \multicolumn{2}{|l|}{ Positional relationship } \\
\hline Skull & Face & Skull & Face & Skull & Face \\
\hline Temporal line & Forehead & Zygion & Zygion & Supraorbital margin & Eyebrow \\
\hline $\begin{array}{l}\text { Lateral line of } \\
\text { zygomatic } \\
\text { bone }\end{array}$ & $\begin{array}{l}\text { Cheek } \\
\text { outline }\end{array}$ & Gonion & Gonion & Medial orbital margin & Endocanthion \\
\hline $\begin{array}{l}\text { Mandibular } \\
\text { line }\end{array}$ & $\begin{array}{l}\text { Lower } \\
\text { jaw } \\
\text { outline }\end{array}$ & Gnathion & Gnathion & $\begin{array}{l}\text { Lateral orbital margin } \\
\text { (Whitnall's malar } \\
\text { tubercle) }\end{array}$ & Ectocanthion \\
\hline- & - & - & - & Orbit & Eye-slit \\
\hline- & - & - & - & $\begin{array}{l}\text { Lateral margin of } \\
\text { piriform aperture }\end{array}$ & Alare \\
\hline- & - & - & - & $\begin{array}{l}\text { Cutting edge of upper } \\
\text { central incisor }\end{array}$ & Stomion \\
\hline- & - & - & - & Teeth (premolar) & Cheilion \\
\hline- & - & - & - & Occlusal line & Oral slit \\
\hline
\end{tabular}

Taken from Yoshino (2012)

\subsubsection{Jayaprakash et al. (2001)}

This is a craniofacial morpho-analytical approach, based on the shape correlation between the skull and face photograph. This approach relies on previous work developed by Lan (1995), İşcan (1993), Farkas (1981), and George (1987, 1993) and special attention is placed on the nasal region. The facial and skull traits and attributes, and the measurements employed for this study are detailed in Tables 3.23, 3.24 , and 3.25. 
Table 3.21 Criteria for assessing anatomical consistency between skull and face in lateral/ oblique view

\begin{tabular}{l|l|l|l|l|l}
\hline Outline & \multicolumn{3}{l|}{ Soft-tissue thickness } & Positional relationship & \\
\hline Skull & Face & Skull & Face & Skull & Face \\
\hline $\begin{array}{l}\text { Frontal bone } \\
\text { contour }\end{array}$ & $\begin{array}{l}\text { Forehead } \\
\text { outline }\end{array}$ & Trichion & Trichion & Supraorbital margin & Eyebrow \\
\hline $\begin{array}{l}\text { Outline from } \\
\text { nasion to } \\
\text { rhinion }\end{array}$ & $\begin{array}{l}\text { Nasal } \\
\text { dorsum } \\
\text { line }\end{array}$ & Glabella & Glabella & $\begin{array}{l}\text { Lateral orbital margin } \\
\text { (Whitnall's malar } \\
\text { tubercle) }\end{array}$ & Ectocanthion \\
\hline $\begin{array}{l}\text { Mental } \\
\text { outline }\end{array}$ & $\begin{array}{l}\text { Chin } \\
\text { outline }\end{array}$ & Nasion & Nasion & Nasion & $\begin{array}{l}\text { Higher than } \\
\text { nasal root }\end{array}$ \\
\hline $\begin{array}{l}\text { Gonial } \\
\text { outline }\end{array}$ & $\begin{array}{l}\text { Jaw angle } \\
\text { outline }\end{array}$ & Rhinion & Rhinion & $\begin{array}{l}\text { Lateral margin of } \\
\text { piriform aperture }\end{array}$ & Alare \\
\hline- & - & $\begin{array}{l}\text { Slightly infe- } \\
\text { rior to } \\
\text { nasospinale }\end{array}$ & Subnasale & $\begin{array}{l}\text { Lower margin of } \\
\text { piriform aperture }\end{array}$ & Subnasale \\
\hline- & - & Pogonion & Pogonion & Incisor & Stomion \\
\hline- & Gnathion & Gnathion & $\begin{array}{l}\text { Teeth (canine } \\
\text { premolar) }\end{array}$ & Cheilion \\
\hline
\end{tabular}

Taken from (Yoshino et al. 1995)

\subsubsection{Ricci et al. (2006)}

The authors presented an algorithm for identification using CFS. Fourteen subjects and their matching facial photographs and skull radiographs were selected. The algorithm calculated the distance of each transferred cross (anatomical points) and the corresponding average. Their results indicate that the smaller the mean value, the greater the index of similarity between the face and the skull. A total of 196 crosscomparisons were carried out. The following tables present the anatomical points that were located and marked with a cross on each facial image (Tables 3.26 and 3.27).

\subsubsection{Ishii et al. (2011)}

This method was based on a study of three subjects, a young man (23 years old), a man with an edentulous upper jaw (36 years old), and a woman (40 years old), using 3D CT data for CFS. Miyasaka (1987), Suzuki (1948), and Ichikawa (1975) studies were used for the morphological assessment technique (Table 3.28). 
Table 3.22 Lines, landmarks and index from Lan (1995)

\begin{tabular}{|c|c|c|c|}
\hline Determining lines & $\begin{array}{l}\text { Landmarks } \\
\text { index }\end{array}$ & $\begin{array}{l}\text { Index of soft } \\
\text { tissue } \\
\text { thickness }\end{array}$ & Index number of index \\
\hline $\begin{array}{l}\text { 1. Ectocanthion line. } \\
\text { Between two ectocanthions, } \\
\text { used as a horizontal base } \\
\text { line to mark the horizontal } \\
\text { relationship of the } \\
\text { superimposition. }\end{array}$ & $\begin{array}{l}\text { Superciliary and } \\
\text { supraorbital line }\end{array}$ & Vertex & $\begin{array}{l}\text { Endocanthion: Distance } \\
\text { between endocanthion and } \\
\text { supraorbital/orbital height }\end{array}$ \\
\hline $\begin{array}{l}\text { 2. Front central line. From } \\
\text { glabella to gnathion, vertical } \\
\text { to the ectocanthion line, } \\
\text { used to mark the vertical } \\
\text { relationship of the } \\
\text { superimposition. }\end{array}$ & Orbital height & Euryon & $\begin{array}{l}\text { Ectocanthion: Distance } \\
\text { between ectocanthion and } \\
\text { supraorbital/Orbital height }\end{array}$ \\
\hline $\begin{array}{l}\text { 3. Superciliary line. } \\
\text { Between two superciliaries, } \\
\text { parallel with the } \\
\text { ectocanthion line, and verti- } \\
\text { cal to the front central line. }\end{array}$ & $\begin{array}{l}\text { Ectocanthion } \\
\text { and supraorbital } \\
\text { line }\end{array}$ & Zygion & $\begin{array}{l}\text { Distance between } \\
\text { Endocanthions: Distance } \\
\text { between bi-endocanthions/ } \\
\text { Distance between junctures } \\
\text { of external orbit }\end{array}$ \\
\hline $\begin{array}{l}\text { 4. Subnasal line. At the } \\
\text { subnasale, vertical to the } \\
\text { front central line, used to } \\
\text { mark the superimposition of } \\
\text { subnasale and infra-apertura } \\
\text { piriformis. }\end{array}$ & $\begin{array}{l}\text { Endocanthion } \\
\text { and supraorbital } \\
\text { line }\end{array}$ & Tragion & $\begin{array}{l}\text { Distance between } \\
\text { Ectocanthions: Distance } \\
\text { between bi-ectocanthions/ } \\
\text { Distance between junctures } \\
\text { of external orbit }\end{array}$ \\
\hline $\begin{array}{l}\text { 5. Cheilion line. Between } \\
\text { two cheilions, vertical to } \\
\text { front central line, used to } \\
\text { mark the superimposition of } \\
\text { cheilion and maxillary teeth. }\end{array}$ & $\begin{array}{l}\text { Subnasale and } \\
\text { infra-apertura } \\
\text { piriformis }\end{array}$ & Gonion & $\begin{array}{l}\text { Stomion line: Distance } \\
\text { between supradental alveo- } \\
\text { lus and stomion line/Dis- } \\
\text { tance between infradental } \\
\text { alveoli and stomion line }\end{array}$ \\
\hline $\begin{array}{l}\text { 6. Gnathion line. At } \\
\text { gnathion, vertical to the } \\
\text { front central line, used to } \\
\text { mark the superimposition of } \\
\text { soft tissue of gnathion and } \\
\text { pogonion. }\end{array}$ & $\begin{array}{l}\text { Cheilion line and } \\
\text { infra-apertura } \\
\text { piriformis }\end{array}$ & Gnathion & $\begin{array}{l}\text { Distance between gonions: } \\
\text { Distance between gonions } \\
\text { on skull/Distance between } \\
\text { gonions on human image }\end{array}$ \\
\hline $\begin{array}{l}\text { 7, 8. Endocanthion vertical } \\
\text { lines (left and right). From } \\
\text { the endocanthion line to the } \\
\text { cheilion line, parallelwith } \\
\text { the front central line, used to } \\
\text { mark the relationship of } \\
\text { endocanthion and maxillary } \\
\text { teeth. }\end{array}$ & $\begin{array}{l}\text { Endocanthion } \\
\text { vertical line to } \\
\text { maxillary tooth } \\
\text { (left) }\end{array}$ & Opisthocranion & $\begin{array}{l}\text { Distance between } \\
\text { cheilions: Distance } \\
\text { between cheilions/ } \\
\text { Distancebetween gonions } \\
\text { on skull }\end{array}$ \\
\hline $\begin{array}{l}9,10 . \text { Ectocanthion vertical } \\
\text { lines (left-right). From the } \\
\text { ectocanthion line to the } \\
\text { gonion line, parallel with the } \\
\text { front central line, and are }\end{array}$ & $\begin{array}{l}\text { Endocanthion } \\
\text { vertical line to } \\
\text { maxillary tooth } \\
\text { (right) }\end{array}$ & Trichion & - \\
\hline
\end{tabular}


Table 3.22 (continued)

\begin{tabular}{|c|c|c|c|}
\hline Determining lines & $\begin{array}{l}\text { Landmarks } \\
\text { index }\end{array}$ & $\begin{array}{l}\text { Index of soft } \\
\text { tissue } \\
\text { thickness }\end{array}$ & Index number of index \\
\hline \multicolumn{4}{|l|}{$\begin{array}{l}\text { used to mark the horizontal } \\
\text { superimposition of } \\
\text { ectocanthion and gonion. }\end{array}$} \\
\hline $\begin{array}{l}\text { Morphological curves } \\
\text { include the following: } \\
\text { (1) head vault curve, } \\
\text { (2) arcus superciliary curve, } \\
\text { (3) nose curve, (4) lower jaw } \\
\text { curve,(5) gonion curve, } \\
\text { (6) head back curve, } \\
\text { (7) forehead curve, } \\
\text { (8) pogonion curve, and } \\
\text { (9) zygomatic curve. }\end{array}$ & $\begin{array}{l}\text { Distance } \\
\text { between two } \\
\text { junctures of } \\
\text { external orbit }\end{array}$ & Glabella & - \\
\hline- & $\begin{array}{l}\text { Distance } \\
\text { between } \\
\text { bi-endocanthions } \\
\end{array}$ & Nasion & - \\
\hline- & $\begin{array}{l}\text { Cheilion to man- } \\
\text { dibular tooth }\end{array}$ & Sellion & - \\
\hline- & $\begin{array}{l}\text { Ectocanthion } \\
\text { and } \\
\text { endoconchion }\end{array}$ & Subnasale & - \\
\hline- & $\begin{array}{l}\text { Prosthion and } \\
\text { cheilion line }\end{array}$ & Pogonion & - \\
\hline- & $\begin{array}{l}\text { Infradentale } \\
\text { anterius and } \\
\text { cheilion }\end{array}$ & - & - \\
\hline- & $\begin{array}{l}\text { Distance } \\
\text { between gonions }\end{array}$ & - & - \\
\hline- & $\begin{array}{l}\text { Distance } \\
\text { between gonions } \\
\text { on the skull }\end{array}$ & - & - \\
\hline- & $\begin{array}{l}\text { Distance } \\
\text { between zygions }\end{array}$ & - & - \\
\hline- & $\begin{array}{l}\text { Distance } \\
\text { between } \\
\text { cheilions }\end{array}$ & - & - \\
\hline- & $\begin{array}{l}\text { Gonion and } \\
\text { tragion on the } \\
\text { skull }\end{array}$ & - & - \\
\hline- & $\begin{array}{l}\text { Gonion and } \\
\text { ectocanthion } \\
\text { vertical line on } \\
\text { the skull }\end{array}$ & - & - \\
\hline
\end{tabular}




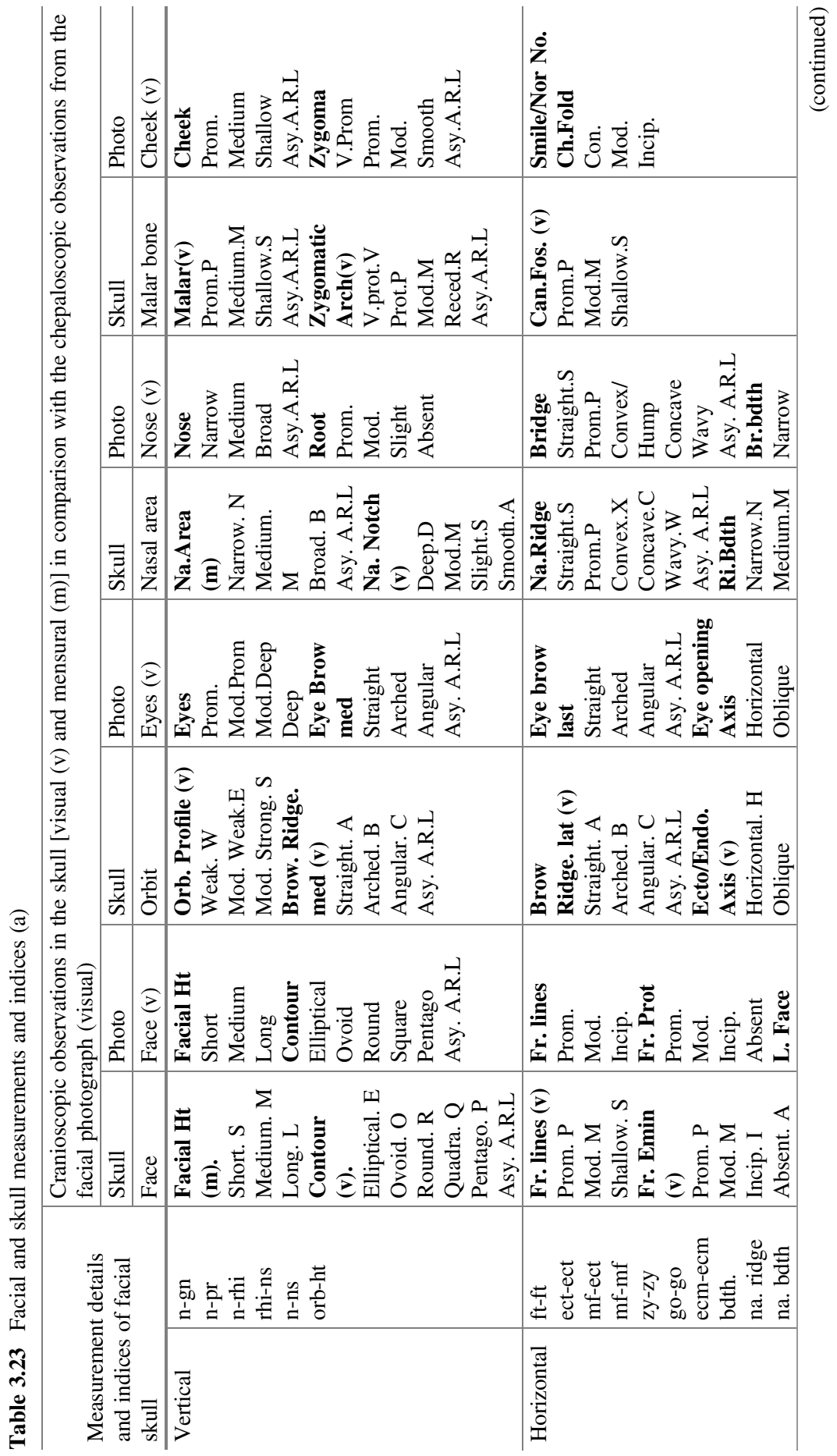




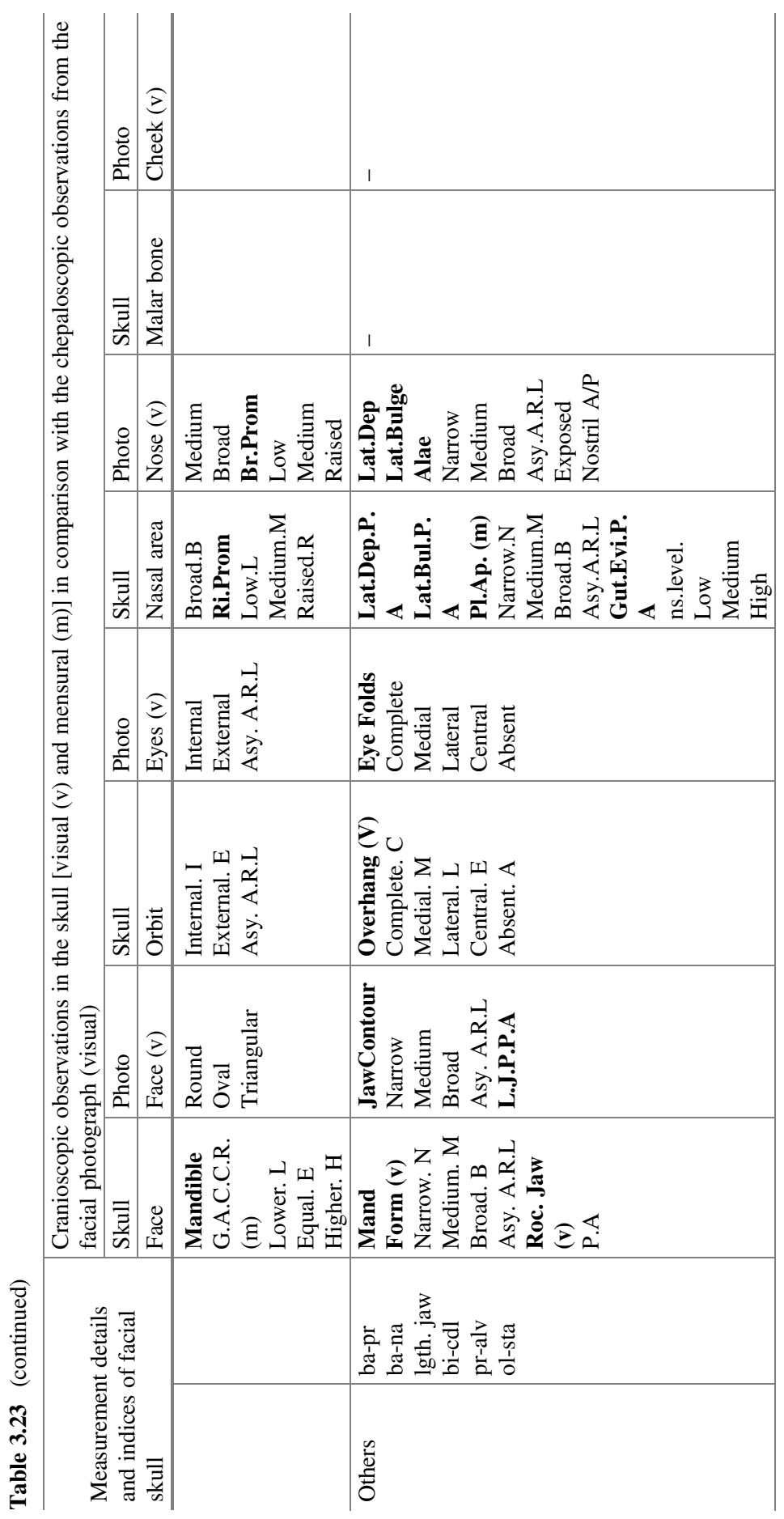




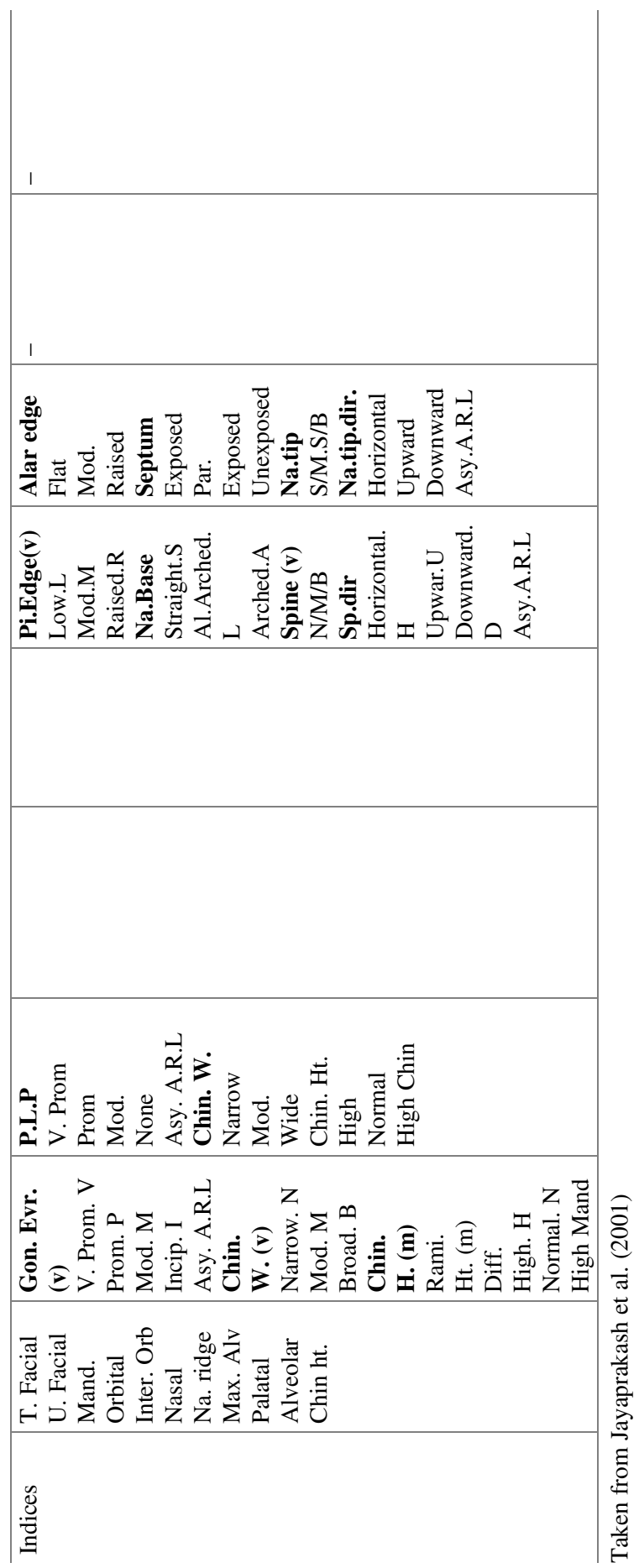




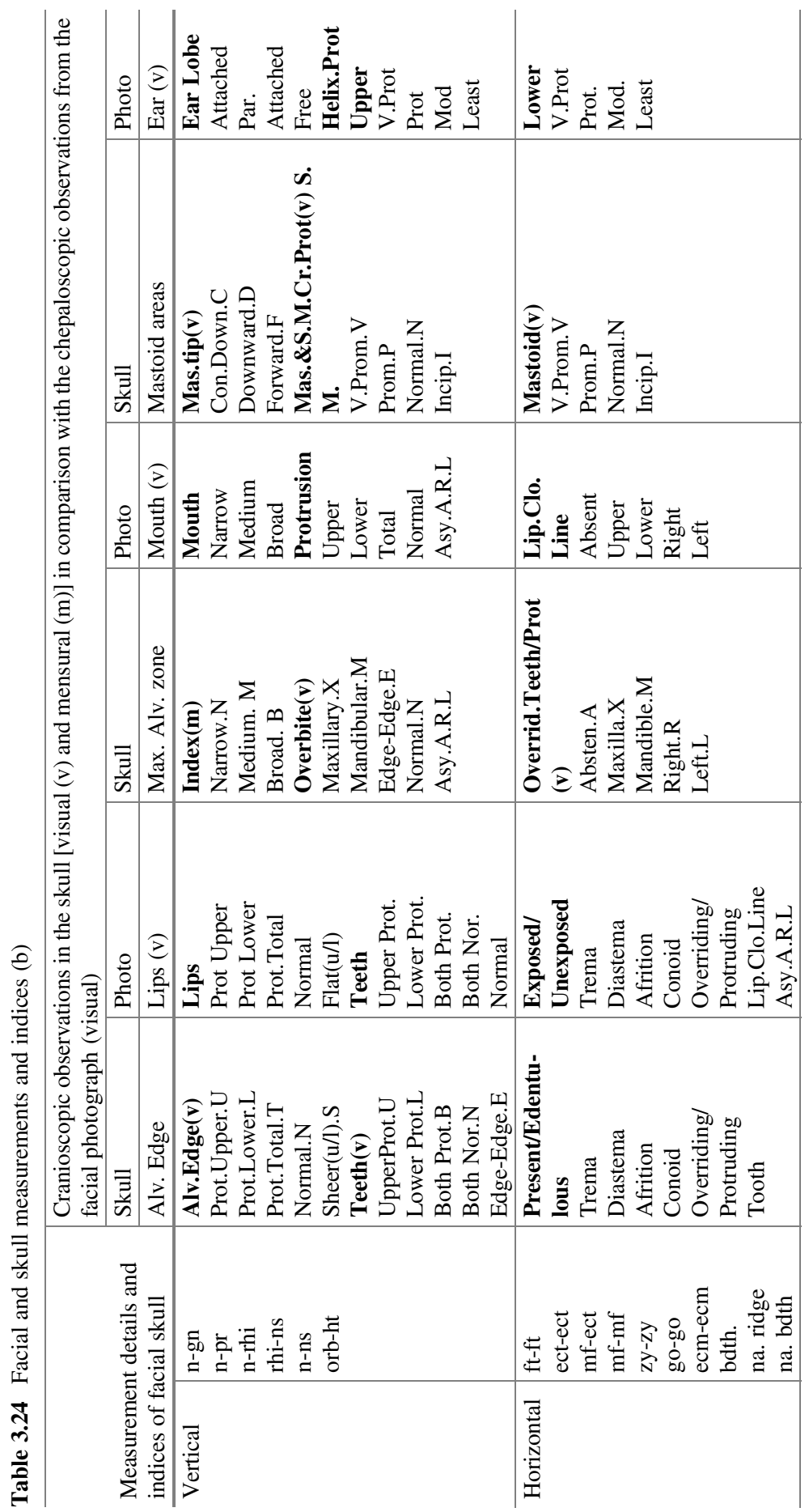




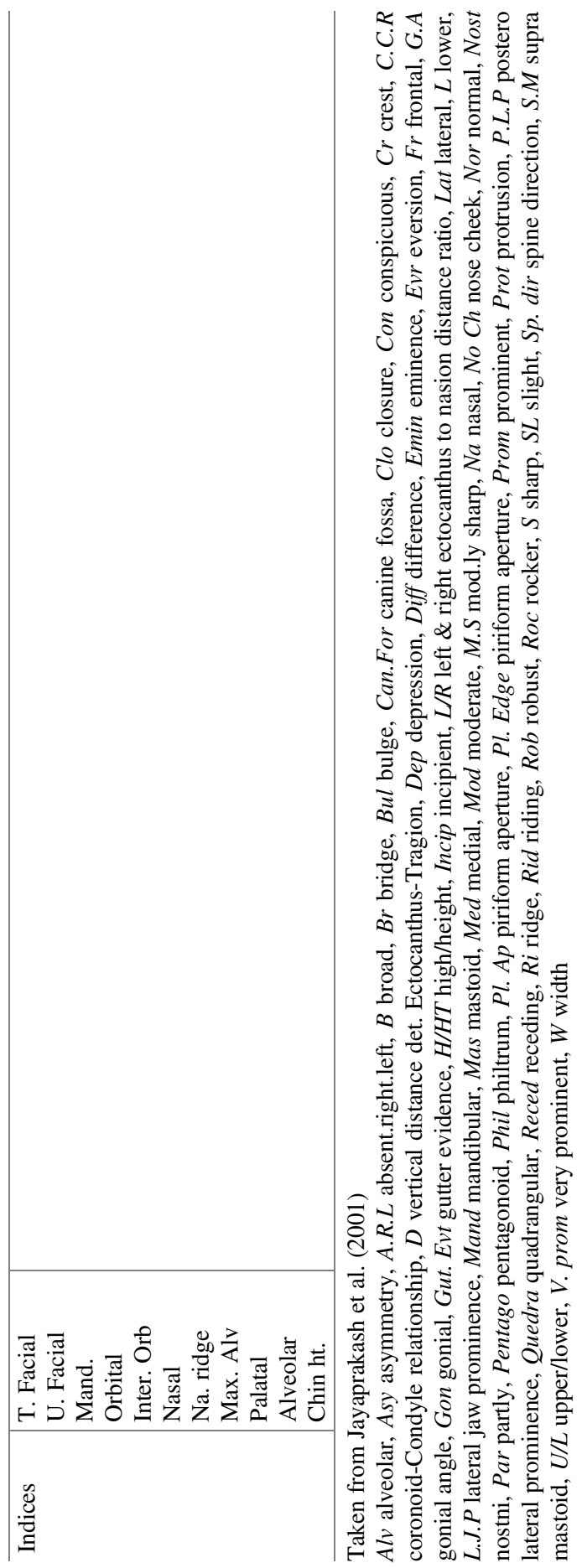




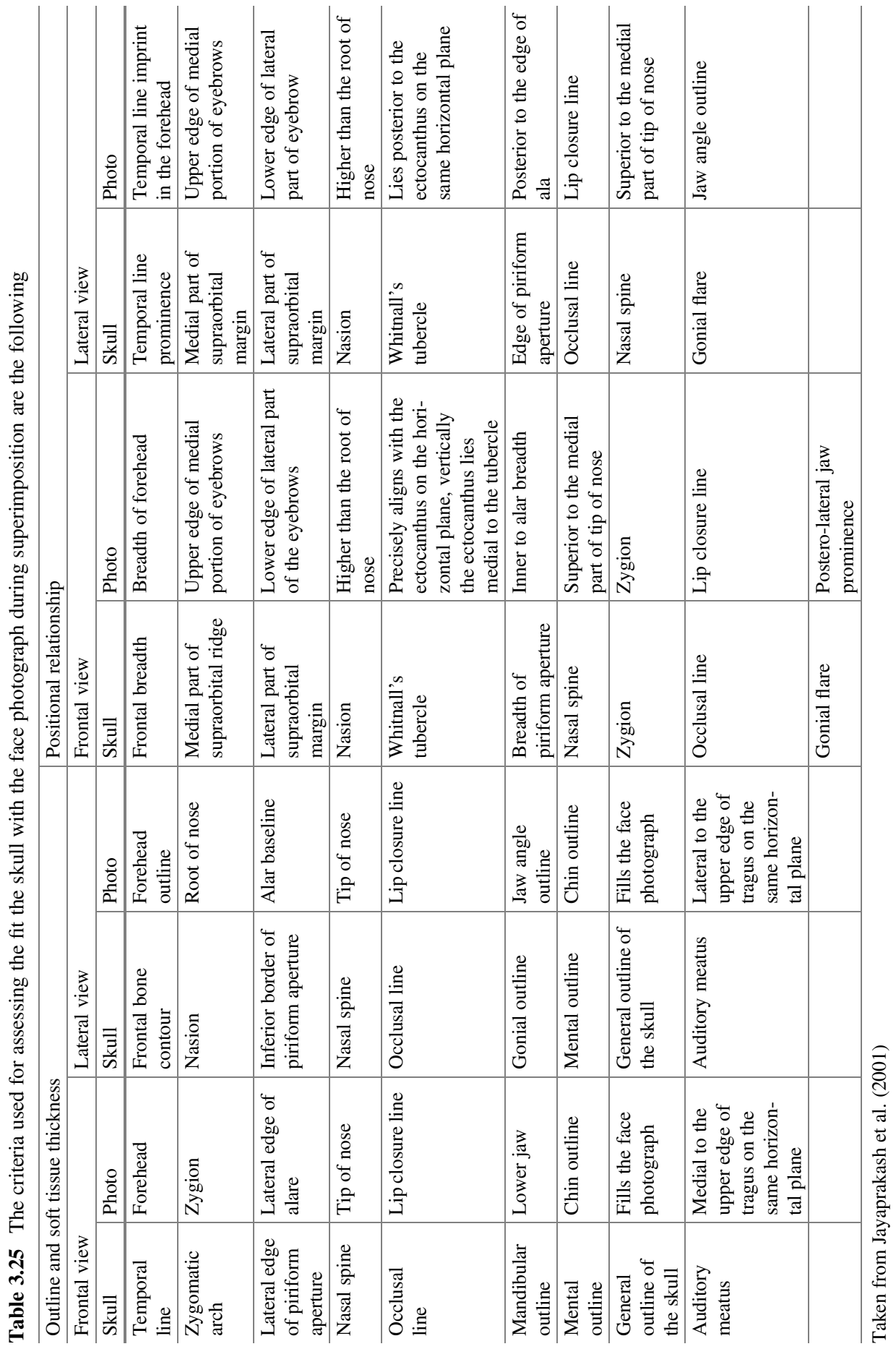


Table 3.26 Anatomical points of the face

Anatomical points of the face

Eyebrow midpoint

Midpoint of the inferior margin of the palpebra inferior (lower eyelid)

Inner canthus

Outer canthus

The most forward point of the midsagittal plane (located between the two eyebrows)

Point below the inferior margin of the cartilaginous septum of the nose

Superior margin of the upper lip midpoint

Inferior margin of the lower lip midpoint

Zygoma

Table 3.27 Points of the skull X-rays

Points of the skull X-rays

Arcus superciliaris midpoint (superciliary arch)

Inferior orbital rim midpoint

Inner canthus, placed $3 \mathrm{~mm}$ medially to the medial wall of the orbit1 or against the medial wall of the orbit 2 or 2-3 mm laterally to the lacrimal crest and $4-5 \mathrm{~mm}$ below the dacryon (junction of the lacromaxillary suture and the frontal bone) 3

Outer canthus, placed $5 \mathrm{~mm}$ laterally to the orbit margin 1 or 3-4 mm medially to the "Whitnall's malar tubercle"3; the "Whitnall's malar tubercle," placed on the orbital surface of the zygomatic bone $11 \mathrm{~mm}$ below the frontozygomatic suture, is the site of attachment of the rectus lateralis bulbi muscle, suspensory ligament, and levator palpebrae superioris muscle 4

Glabella

Inferior margin of the nasal spine

Upper infradental point (between the two medial upper incisors)

Lower infradental point (between the two medial lower incisors)

Zygomatic process of the maxilla

Table 3.28 Anthropometrical points used for each individual

\begin{tabular}{l|l}
\hline Landmarks & \\
\hline $\mathrm{n}$ & R-ex \\
\hline R-zy & L-ex \\
\hline L-zy & sn-ns \\
\hline gn & R-al \\
\hline R-go & L-al \\
\hline L-go & R-ch \\
\hline R-en & L-ch \\
\hline L-en & - \\
\hline
\end{tabular}

$n$ nasion, $R$-zy right zygion, $L$-zy left zygion, $g n$ gnathion, $R$ - $g o$ right gonion, $L$-go left gonion, $R$-en right endocanthion, $L$-en left endocanthion, $R$-ex right exocanthion, $L$-ex left exocanthion, $s n$-sn subnasal-subnasal, $R$-al right alare, $L$-al left alare, $R$-ch cheilion, $L$-che left cheilion 
Table 3.29 Orientation, primary, and secondary landmarks

\begin{tabular}{|c|c|}
\hline Methods & Description \\
\hline \multicolumn{2}{|l|}{ Orientation landmarks } \\
\hline Ectocanthion (ec) & \multirow[t]{3}{*}{ Should overlap: used to define the orientation } \\
\hline Subnasal point (ns) & \\
\hline Nasion (n) & \\
\hline \multicolumn{2}{|l|}{ Primary landmarks } \\
\hline Glabella $(\mathrm{g})$ & \multirow{3}{*}{$\begin{array}{l}\text { Expected to be very close on skull and face, landmarks should touch or } \\
\text { overlap }\end{array}$} \\
\hline Dacryon (d) & \\
\hline Frontotemporale $(\mathrm{ft})$ & \\
\hline \multicolumn{2}{|l|}{ Secondarylandmarks } \\
\hline Gonial angle (go) & \multirow{4}{*}{$\begin{array}{l}\text { Bone and soft tissue landmarks not expected to overlap exactly but } \\
\text { bony landmarks should be inside soft tissue landmarks }\end{array}$} \\
\hline Gnathion (gn) & \\
\hline Zygion (zy) & \\
\hline $\begin{array}{l}\text { Nasal aperture width/ } \\
\text { alare (al) }\end{array}$ & \\
\hline
\end{tabular}

The description of the landmark on the skull (bony landmark) and the corresponding soft tissue landmark is given. Taken from Gordon and Steyn (2012)

\subsubsection{Gordon et al. (2006)}

The authors studied three methods: basic morphological matching (Austin-Smith and Maples 1994), landmark matching, and a combination of both approaches. The bony and soft tissue landmarks used were based on Martin and Saller (1957) and Farkas (1981). They proposed three different sets of landmarks for orientation and evaluation purposes for CFS (see Table 3.29).

Open Access This chapter is licensed under the terms of the Creative Commons AttributionNonCommercial 2.5 International License (http://creativecommons.org/licenses/by-nc/2.5/), which permits any noncommercial use, sharing, adaptation, distribution and reproduction in any medium or format, as long as you give appropriate credit to the original author(s) and the source, provide a link to the Creative Commons license and indicate if changes were made.

The images or other third party material in this chapter are included in the chapter's Creative Commons license, unless indicated otherwise in a credit line to the material. If material is not included in the chapter's Creative Commons license and your intended use is not permitted by statutory regulation or exceeds the permitted use, you will need to obtain permission directly from the copyright holder. 